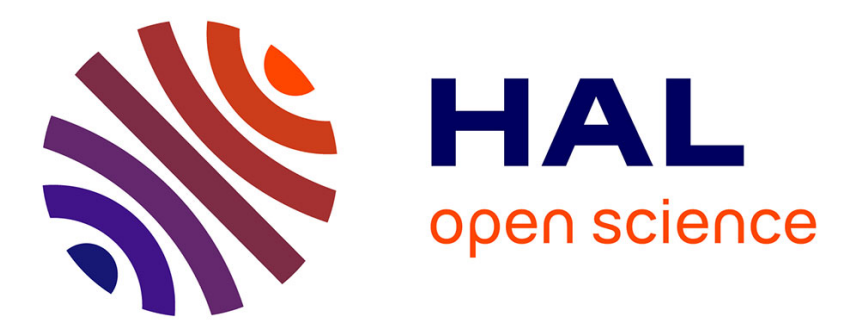

\title{
Coulomb theory applied to accretionary and nonaccretionary wedges: Possible causes for tectonic erosion and/or frontal accretion
}

\author{
Serge E. Lallemand, Philippe Schnürle, Jacques Malavieille
}

\section{To cite this version:}

Serge E. Lallemand, Philippe Schnürle, Jacques Malavieille. Coulomb theory applied to accretionary and nonaccretionary wedges: Possible causes for tectonic erosion and/or frontal accretion. Journal of Geophysical Research, 1994, 99 (B6), pp.12033-12055. hal-01261600

\author{
HAL Id: hal-01261600 \\ https://hal.science/hal-01261600
}

Submitted on 25 Jan 2016

HAL is a multi-disciplinary open access archive for the deposit and dissemination of scientific research documents, whether they are published or not. The documents may come from teaching and research institutions in France or abroad, or from public or private research centers.
L'archive ouverte pluridisciplinaire HAL, est destinée au dépôt et à la diffusion de documents scientifiques de niveau recherche, publiés ou non, émanant des établissements d'enseignement et de recherche français ou étrangers, des laboratoires publics ou privés. 


\title{
Coulomb theory applied to accretionary and nonaccretionary wedges: Possible causes for tectonic erosion and/or frontal accretion
}

\author{
Serge E. Lallemand \\ URA CNRS 1760 "Géophysique et Tectonique", Université Montpellier II, Montpellier, France
}

\author{
Philippe Schnürle \\ URA CNRS 1315, Laboratoire de Géologie Structurale, Université Pierre et Marie Curie, Paris, France
}

Jacques Malavieille

URA CNRS 1760 "Géophysique et Tectonique", Université Montpellier II, Montpellier, France

\begin{abstract}
Based on observations from both modem convergent margins and sandbox modeling, we examine the possible conditions favoring frontal accretion and/or frontal and basal tectonic erosion. Mean characteristic parameters $\left(\mu, \mu_{b}^{*}\right.$ and $\left.\lambda\right)$ are used to discuss the mechanical stability of 28 transects across the frontal part of convergent margins where the Coulomb theory is applicable. Natural observations reveal that "typical accretionary wedges" are characterized by low tapers with smooth surface slope and subducting plate, low convergence rates and thick trench sediment, while "nonaccretionary wedges" display large tapers with irregular surface slopes and rough subducting plate, high convergence rates and almost no trench fill. Sandbox experiments were performed to illustrate the effects of seamounts/ridges in the subduction zone on the deformation of an accretionary wedge. These experiments show that a wedge of sand is first trapped and pushed in front of the seamount which acts as a moving bulldozer. This is followed by a tunnelling effect of the subducting seamount through the frontal wedge material, which results in considerable sand reworking. At an advanced subduction stage, the décollement jumps back from a high level in the wedge to its former basal position. We conclude that a high trench sedimentation rate relative to the convergence rate leads to frontal accretion. In contrast, several conditions may favor tectonic erosion of the upper plate. First, oceanic features, such as grabens, seamounts or ridges, may trap upper plate material during their subduction process. Second, destabilization of the upper plate material by internal fluid overpressuring causing hydrofracturing is probably another important mechanism.
\end{abstract}

\section{Introduction}

Following work by Davis et al. [1983] on the mechanics of fold and thrust belts, Dahlen [1984] derived a rigorous solution for the "critical taper" that a submarine sediment wedge of noncohesive frictional material on a basal plane of weakness will attain, when sufficiently compressed from its back end. The rock is treated as a frictional plastic (Coulombtype) material without cohesion. A cohesive plastic material without frictional shear strength has been previously investigated by Chapple [1978]. This material model thus neglects elastic strains and strain hardening and softening and the limiting condition will be given by the effective-stressdependent internal friction of Coulomb-Mohr [Mandl, 1988].

Since that time, numerous authors have applied the "Coulomb theory" to accretionary wedges to estimate some characteristic parameters [e.g., Dahlen et al., 1984; Zhao et al., 1986]. Three parameters are sufficient to calculate the

Copyright 1994 by the American Geophysical Union.

Paper number 94JB00124.

0148-0227/94/94JB-00124\$05.00 "critical taper" at failure for a given rock density within the wedge. These parameters are the internal and effective-basal friction angles and pore fluid pressure in the wedge. In this paper we apply this theory both to accretionary and nonaccretionary wedges using 28 well-constrained geometries of convergent margins.

We use the classification of convergent margins as defined by von Huene and Scholl [1991, 1993], depending on the occurrence or absence of an accretionary wedge (or prism or complex) at the toe of the active margins. Such a complex is generally well imaged on seismic records because of its particular fold and thrust structure. The complex continuously grows by incorporation of new imbricate slices of trench fill and oceanic material or by underplating along accreting margins (Figure 1). On the other hand, the wedge either maintains its initial volume or consumes itself by tectonic erosion at nonaccreting margins (Figure 1). Both sediment accretion at the toe and crust consumption further back may occur simultaneously as is documented along some transects of the Japan and Peru Trenches [von Huene and Lallemand, 1990].

Several authors have demonstrated that considerable loss of upper plate material has occurred along some convergent margins through tectonic erosion processes [e.g., von Huene 
NON-ACCRETIONARY MARGINS (21,000 KM) $100 \%$ SEDIMENT UNDERTIJRUST

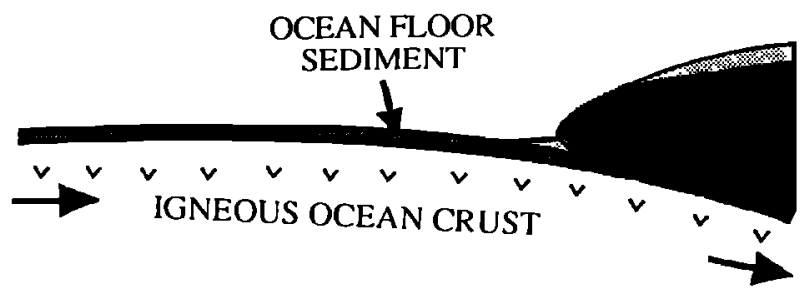

INTERMEDIATE-ACCRETIONARY MARGINS (16,000 KM) $80 \%$ SEDIMENT UNDERTHRUST

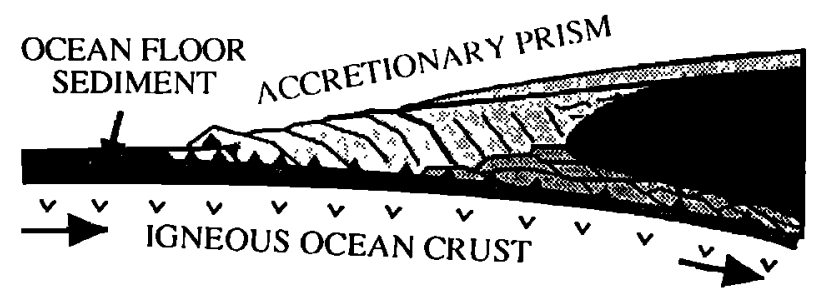

TYPICAL-ACCRETIONARY MARGINS (7,000 KM) 70\% SEDIMENT UNDERTHRUST

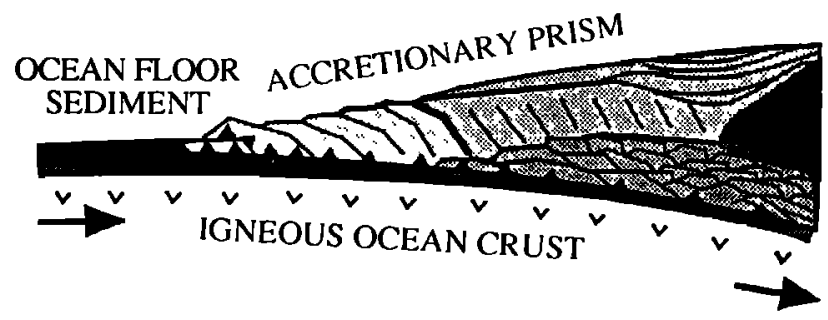

Figure 1. Classification of convergent margins as proposed by von Huene and Scholl [1993, p. 168] with their cumulative length of occurrence. In this paper we call "intermediate accretionary wedges" what von Huene and Scholl called "accretionary wedges with small prisms (5-40 km wide)" and "typical accretionary wedges" what they called "accretionary wedges with large prisms (> $40 \mathrm{~km}$ wide)." and Lallemand, 1990; von Huene and Scholl, 1991; Lallemand et al., 1992a]. For example, the Japan and Peru submarine wedges probably decreased their volume by about $50 \%$ during the Neogene. Lallemand [1992] compiled the subduction zones where great subsidence together with volcanic front retreat were documented. These "erosional" margins include northern Japan, Peru, Izu-Bonin, Mariana, Tonga and Guatemala - Costa Rica. Although the loss of upper plate material appears quite certain, especially in the light of the great subsidence recorded along these margins, the mechanism responsible is still poorly known. Several explanations have been proposed such as the wedging of positive relief features into the subduction zones (Japan, Peru, Tonga) causing frontal erosion [von Huene and Lallemand, 1990; Lallemand et al., 1990], the fragmentation of the upper plate by hydrofracturing leading to basal erosion [von Huene and Lee, 1983; Platt, 1990] or a normal geological mode for a convergent margin where the trench fill does not exceed $500 \mathrm{~m}$ in thickness [Le Pichon and Henry, 1992].

To investigate the possible causes of tectonic erosion and/or sediment accretion, we review some of the parameters of active margins such as the convergence rate and the occurence of grabens or seamounts on the subducting plate. We also use laboratory sandbox models to illustrate possible mechanisms of basal and frontal erosion of the overriding plate.

\section{The Coulomb Theory Applied to Accretionary Wedges}

\section{Previous Studies}

As a first approximation, we assume that accretionary prisms behave as homogeneous wedges formed of noncohesive Coulomb material frictionally sliding on a rigid base (subducting plate). This theory is scale-independent. The maximum depth of applicability is given by the downward increase in temperature and corresponds to the transition from a pressure-dependent, time-independent Coulomb behavior to a pressure-independent, temperature-dependent plastic behavior [Davis et al., 1983]. This transition occurs at variable depths, depending on the thermal gradient, generally at $15 \pm 5 \mathrm{~km}$ depth.

We use the exact solution of Dahlen [1984] for a critical

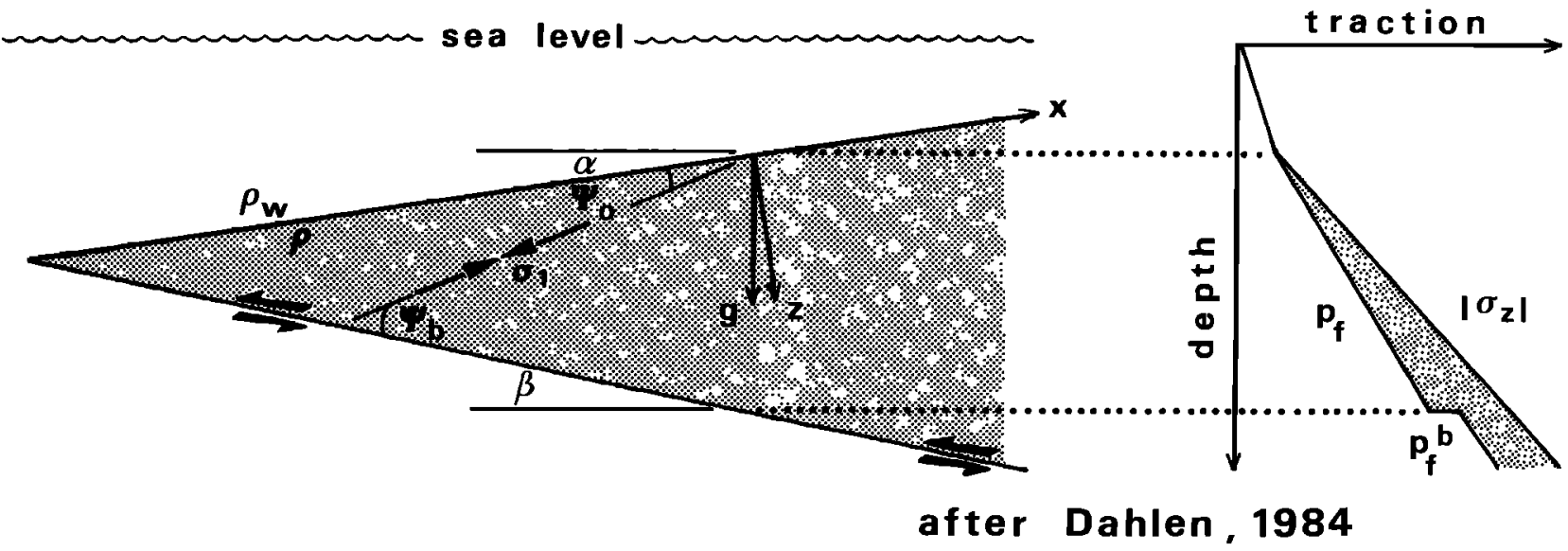

Figure 2. Cross-sectional sketch of a submarine noncohesive critical wedge showing the Cartesian coordinates $\mathrm{x}, \mathrm{z}$ and the angles $\alpha, \beta, \psi_{0}$, and $\psi_{\mathrm{b}}$. Strength in the wedge is proportional to the effective stress $\sigma_{\mathrm{Z}}$, shown schematically by the shaded area on the right. Modified after Dahlen [1984]. 
taper. Let $\alpha$ and $\beta$ be the topographic slope angle and the related décollement angle (Figure 2 ). $\psi_{b}$ and $\psi_{0}$ are the angles between the maximum compressive stress $\sigma_{1}$ and the base and seafloor, respectively. If the wedge is uniform and noncohesive, then the orientation of $\sigma_{1}$ is everywhere the same ( $\Psi_{0}$ is a constant). Dahlen [1984] demonstrated that the following three equations ((9), (17) and (19) in his paper) are sufficient to determine the exact critical taper and the slip lines orientation in every part of the stability field diagram as a function of surface slope $\alpha$ and basal dip $\beta$ (Figure 2).

$$
\begin{gathered}
\alpha+\beta=\Psi_{b}-\psi_{0} \\
\psi_{0}=\frac{1}{2} \arcsin \left(\frac{\sin \alpha^{*}}{\sin \phi}\right)-\frac{1}{2} \alpha^{*} \\
\psi_{b}=\frac{1}{2} \arcsin \left(\frac{\sin \phi_{b}{ }^{*}}{\sin \phi}\right)-\frac{\phi_{b}{ }^{*}}{2}
\end{gathered}
$$

with the effective angle of basal friction,

$$
\phi_{b}^{*}=\arctan \left[\mu_{b}\left(\frac{1-\lambda_{b}}{1-\lambda}\right)\right],
$$

and the "modified" slope angle,

$$
\left.\alpha^{*}=\arctan \frac{\left(1-p_{w} / \rho\right)}{(1-\lambda)} \tan \alpha\right)
$$

Variables $\phi$ and $\phi_{b}$ are the internal and basal friction angles. The internal and basal friction coefficients are $\mu=\tan \phi$ and $\mu_{b}$ $=\tan \phi_{b}$. Variables $\lambda$ and $\lambda_{b}$ are the internal and basal pore fluid pressure ratios corresponding to $\left(P_{f}-P_{\text {cealoor }}\right) /\left(\sigma_{z}-P_{\text {seaboor }}\right) ; P_{f}$ is the pore fluid pressure and $\sigma_{2}$ is the lithostatic pressure along an axis normal to the seafloor. Variables $\rho_{w}$ and $\rho$ are the densities of water and rocks respectively.

Discussion About Some Characteristic Parameters

The reliability of the characteristic parameters previously described need to be discussed, as there exists an infinity of solutions $\left(\mu, \mu_{b}^{*}=\tan \phi_{b}^{*}, \lambda\right)$ which account for the stability of a given wedge. Furthermore, it is very difficult to measure these parameters in situ. Table 1 summarizes the few measurements that are presently available.

Variables $\mu$ and $\mu *_{b}$ are deduced from structural considerations of conjugate thrust faults occurring at the toe of some wedges. Hafner [1951] has shown that the Coulomb criterion is satisfied along two conjugate slip planes inclined about the $\sigma_{1}$ axis at angles $\theta= \pm\left(45^{\circ}-\phi / 2\right)$. Thus the sum of the basal step-up angles of newly formed conjugate thrusts corresponds to $90^{\circ}-\phi$ (Figure 3). From these data, we can easily derive $\mu=\tan \phi$ and $\psi_{b}$, which allow us to calculate $\mu_{b}$ according to equation (3). Davis and von Huene [1987] used this method for the first time to derive these parameters from Aleutian accretionary prism data. We also applied this method for the Oregon and Nankai accretionary prisms, which exhibit pop-up structures at the toes of their accretionary wedges assuming that forethrust and backthrust are conjugate and newly formed. The data we used were multichannel seismic lines NT 62-8 [Moore et al., 1990a] for the Nankai wedge and WO76-4 [Moore et al., 1990b] for the Oregon wedge. Most of the values of pore fluid pressure ratio $\lambda$ were derived from already published well measurements [Davis et al., 1983].

Our mean values of $\mu$ and $\mu_{b}$ are both based on three measurements and are obviously only representative for some accretionary wedge toes. As these values differ considerably from the mean value for Taiwan of 1.03 used, for example, by Davis et al. [1983], assuming that Byerlee's law is valid at the base $\left(\mu_{b}=0.85\right)$, we will adopt the value of $\mu=0.52$ averaged among three in situ measurements with an uncertainty of about $20 \%$, rather than any other empirical value deduced from laboratory experiments [Byerlee, 1978]. Furthermore, the method used by Davis and von Huene [1987] allows $\mu^{*}$ to be determined directly without knowing $\mu_{b}, \lambda$ and $\lambda_{b}$. In the same way, the mean value of $\lambda=0.88$ is averaged from five well measurements with an uncertainty of about $10 \%$ (Table 1 ).

Table 1. Summary of Available Characteristic Parameters

\begin{tabular}{cccc}
\hline Measured Values & $\mu$ & $\mu^{*}{ }_{b}=\mu_{b}\left(1-\lambda_{b}\right) /(1-\lambda)$ & $\lambda$ \\
\hline Taiwan & - & - & $0.675 \pm 0.05 *$ \\
Aleutian & $0.45 \pm 0.09 \dagger$ & $0.28 \pm 0.07 \dagger$ & $\approx 0.87 \neq$ \\
Nankai & $0.50 \pm 0.10$ & $0.20 \pm 0.10$ & - \\
Guatemala & - & - & high \\
Oregon & $0.62 \pm 0.10$ & $0.23 \pm 0.10$ & $0.85 \pm 0.03^{\prime \prime}$ \\
Barbados & - & - & $\approx 1^{\text {q }}$ \\
Makran & - & - & $\approx 1^{* *}$ \\
Mean values & $0.52 \pm 0.10$ & $0.24 \pm 0.09$ & $0.88 \pm 0.08$ \\
& & &
\end{tabular}

Variables $\mu, \mu_{b}$ and $\lambda$ were measured in accretionary wedges and partly published by Davis et al. [1983].

* From well measurements [Suppe and Witte, 1977],

+ From structural considerations of conjugate thrust faults at the loe of the wedge [Davis and von Huene, 1987],

₹ From well data [Hottman et al., 1979],

8 This was deduced from well data [Aubouin et al., 1982],

"From well data [Moore and von Huene, 1980].

9 From well measurements (packer) [Moore et al., 1982],

** From well data, private communication to Davis et al. [1983].

The values in bold were calculated by the authors from structural considerations of conjugate thrust faults at the toe of wedges using the method of Davis and von Huene [1987]. 


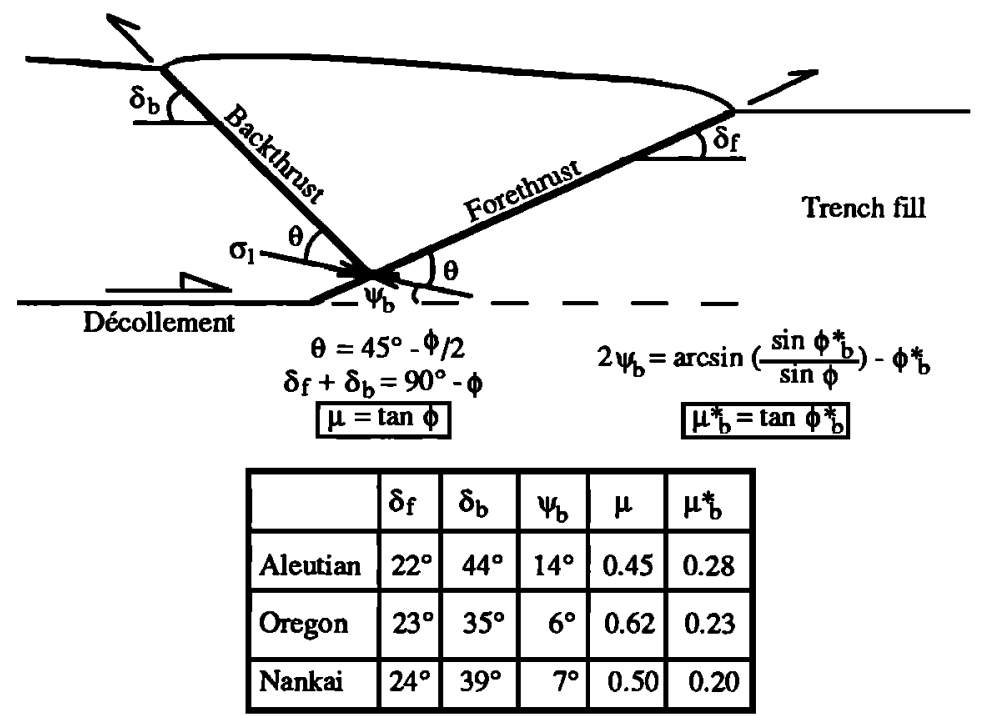

Figure 3. Sketch showing the method used by Davis and von Huene [1987] to determine, for the Aleutian Trench, the "internal" and "basal effective" coefficient of friction at the toe of a wedge. We have used the same method to calculate these parameters in the Oregon and Nankai trenches where pop-up structures are observed at the toe of the wedges.

Figure 4 is an example of a stability field diagram based on equations (1), (2) and (3), using mean values of characteristic natural parameters (see Table 1 ). The mean rock density has been taken as $2300 \mathrm{~kg} / \mathrm{m}^{3}$. The tectonic regimes (compressive, extensive) of critical tapers along the envelope are labeled on Figure 4. Two restrictions can be made concerning this averaged stability field. First, mean values were deduced from parameters measured in typical accretionary wedges. Consequently, the proposed mean envelope is not necessarily representative of nonaccretionary wedges. Second, the error bars for each parameter are significant. We have indicated the uncertainty on each characteristic parameter within smaller diagrams (Figure 4 ) drawn for some realistic sets of values $\left(-4^{\circ} \leq \alpha \leq 14^{\circ}, 0^{\circ} \leq \beta \leq 20^{\circ}\right)$. The uncertainties are those mentioned in Table 1, i.e. $\mu \pm 20 \%, \mu_{b} \pm 40 \%$ and $\lambda$ $\pm 10 \%$. We note that the locus of the stability field in an ( $\alpha$, $\beta$ ) diagram is not very sensitive to variations of friction $\mu$ and $\mu^{*}$, but is highly sensitive to variation of pore fluid pressure $\lambda$.

\section{Lessons from natural wedges}

\section{Taper variations}

Before examining the mechanical control of accretion or erosion, let us consider the present distribution of convergentmargin tapers on a mean stability diagram. For that purpose, we have studied 28 well-constrained transects of "typical accretionary," "intermediate" and "nonaccretionary" wedges that are listed in Table 2 (see location on Figure 5). We chose nine transects representative of typical accretionary wedges (according to the literature). Five of these are located in the Lesser Antilles area to examine latitudinal variations of taper within a given subduction zone. We have classified 11 other transects as "intermediate" accretionary wedges characterized by small accretionary prisms. Five of these transects are located along the Japan Trench to examine lateral variations. Finally, eight transects were selected among wedges without accretionary prism and generally characterized by tectonic erosion. Five of these are located in the Tonga - northern Kermadec Trench.

We have plotted the mean representative tapers for each of the 28 transects on a mean stability field diagram (Figure 6) similar to those of Figure 4 . Table 2 summarizes the different frontal tapers considering mean $\alpha$ and $\beta$ measured from the trench back to a vertical line corresponding to a décollement depth of $10 \mathrm{~km}$ below seafloor. We have used published depth sections (sources are given in Table 2) for estimating the dip angle of the décollement. Because of the time/depth conversion uncertainty, we consider that the error on $\beta$ can reach $\pm 20 \%$. Inasmuch as the stability field is elongated in the $\beta$ direction, variations in $\beta$ do not severely affect the conclusions.

We observe that typical accretionary wedge tapers are close

Figure 4. Stability field diagram for critical wedges (surface slope $\alpha$ versus basal dip $\beta$ ) using mean measured friction angles and pore fluid pressure ratio, i.e., $\mu=0.52 ; \mu_{b}^{*}=0.24 ; \lambda=0.88 ; \rho_{w}=1030 \mathrm{~kg} / \mathrm{m}^{3}$ and $\rho=$ $2300 \mathrm{~kg} / \mathrm{m}^{3}$ (mean density for a 0 - to $10-\mathrm{km}$ wedge thickness [Lallemand et al., 1992a]). Slip lines are plotted along the stability field envelope which coincides with critical tapers. The box outlines the set of reaiistic values of $(\alpha, \beta)$ for natural wedges. We have plotted the error estimates of the three characteristic parameters: $\mu$ $\pm 20 \% ; \mu^{*} \mathrm{~b} \pm 40 \% ; \lambda \pm 10 \%$ in the top three diagrams. Solid circles correspond to the mean tapers of the 28 natural transects listed in Table 2 and labeled in Figure 6 . Note the high sensitivity of the area of the stability field to the pore fluid pressure variations and conversely the low sensitivity of the coefficients of friction. 

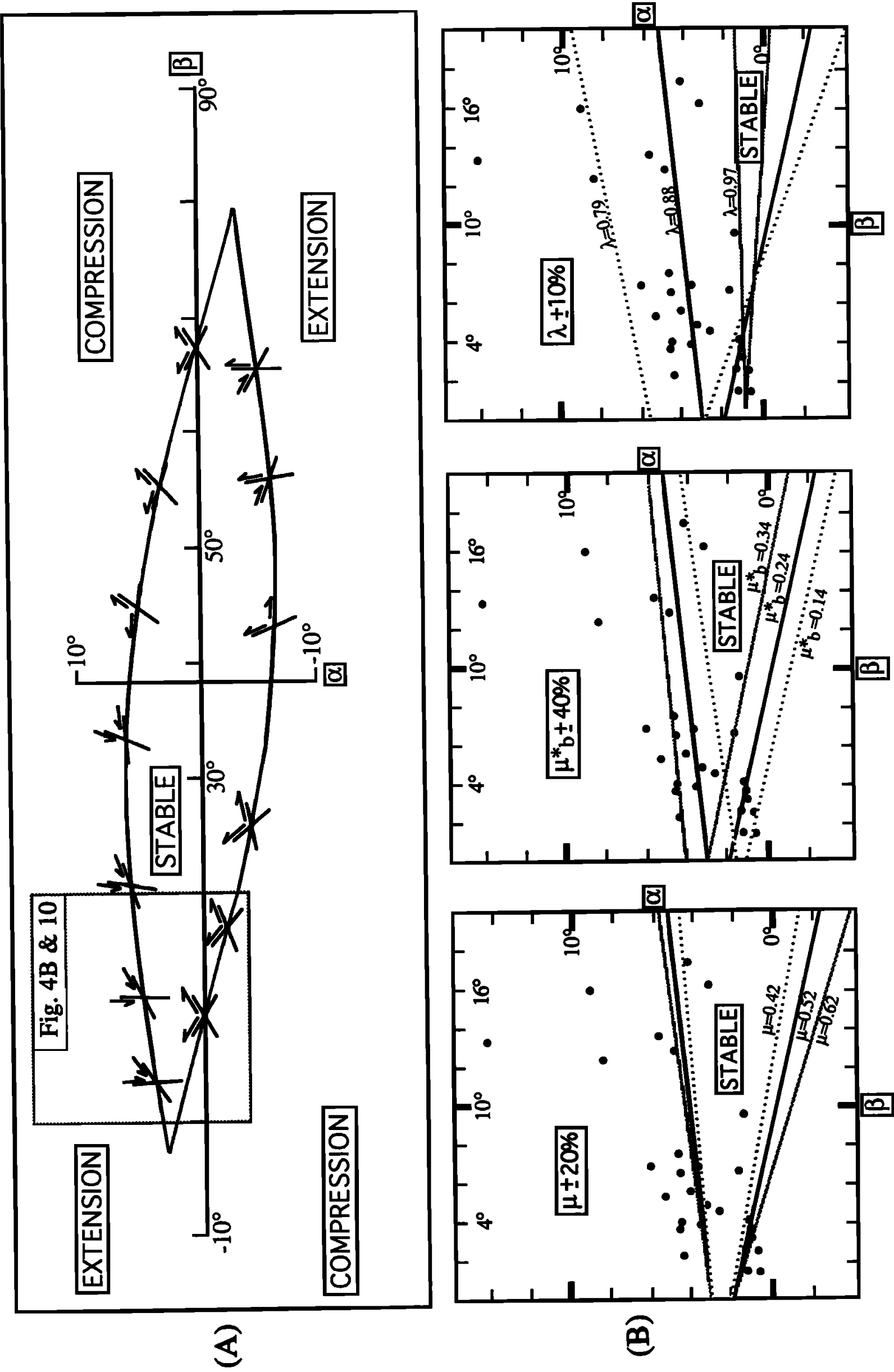


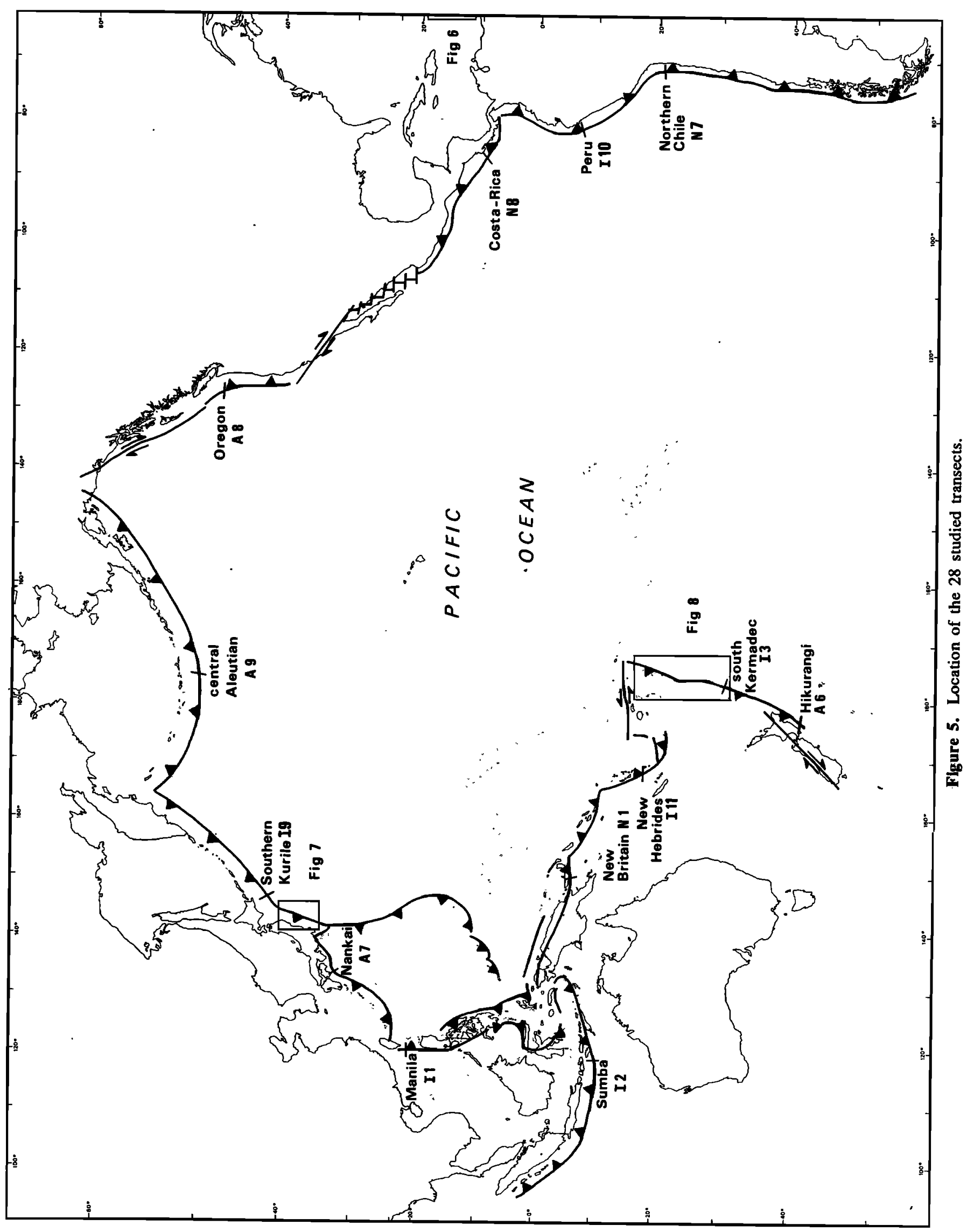




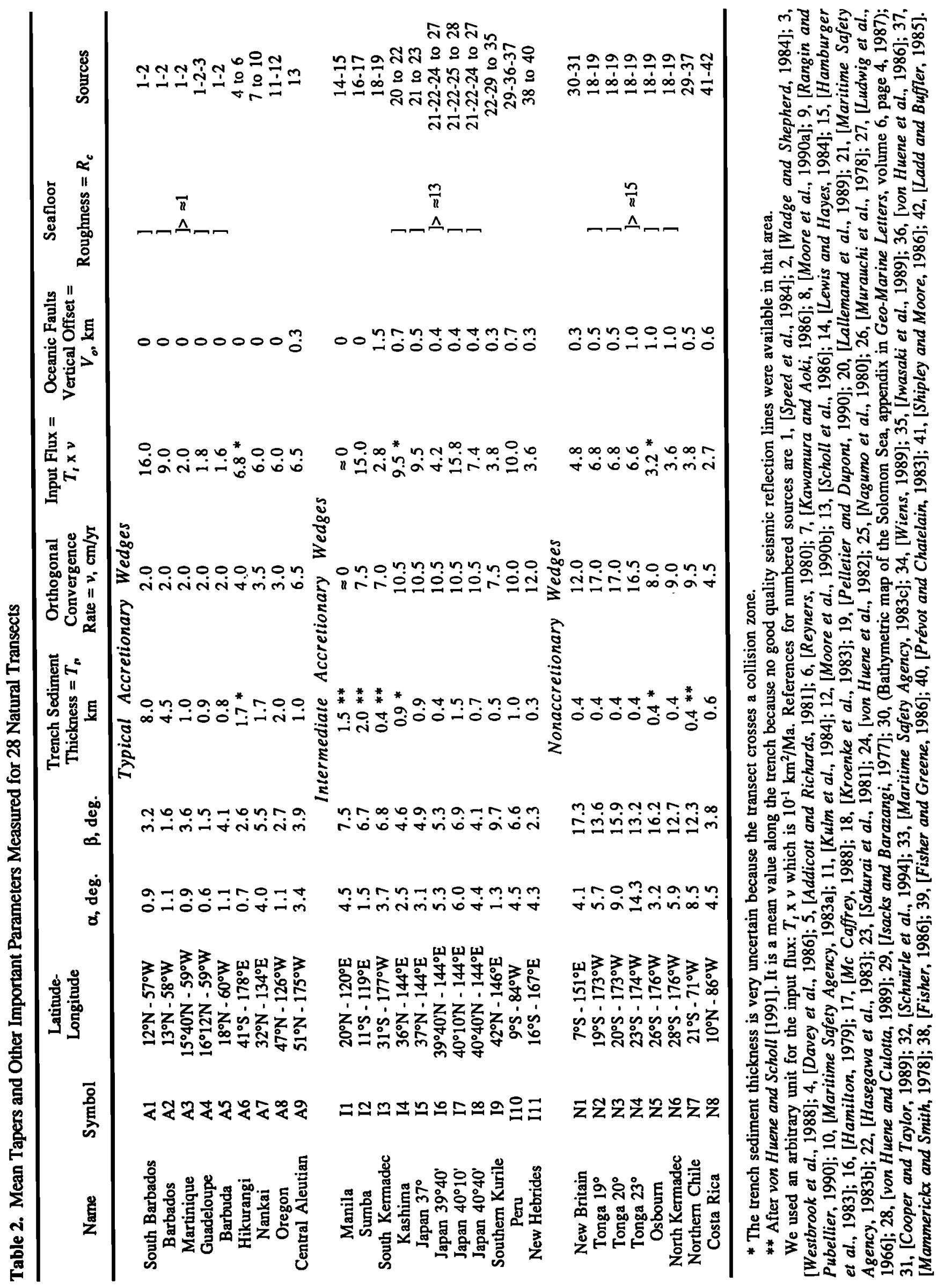




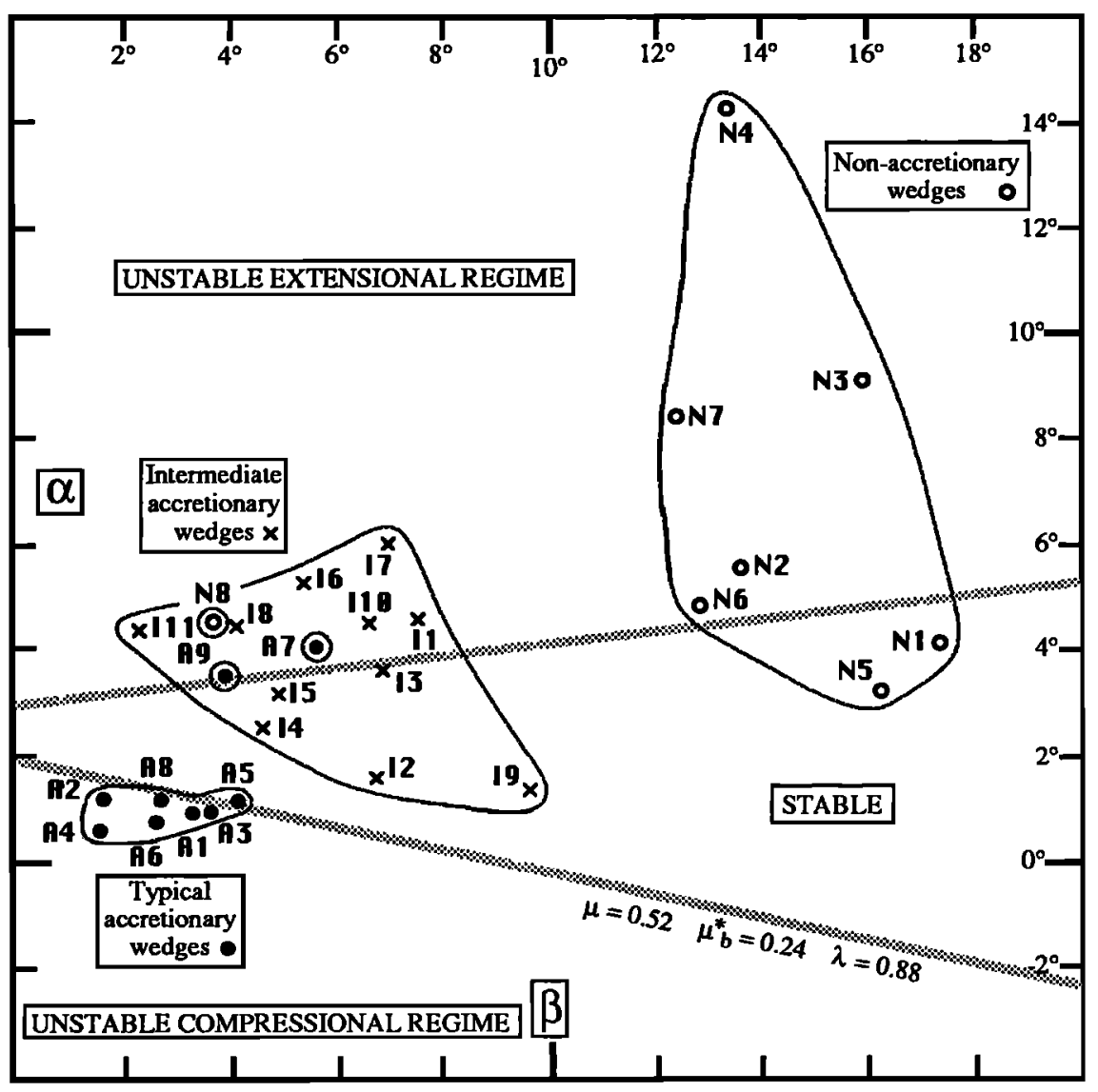

Figure 6. Enlarged view of the observed stability field (see Figure 4 for location), with the mean tapers of the 28 transects plotted and labeled (see values in Table 2). The three groups of wedges are clearly distinct on that diagram except some wedges such as Nankai, Aleutian and Costa Rica. See the text for further explanation.

to each other $\left(0.6^{\circ} \leq \alpha \leq 1.1^{\circ}\right.$ and $\left.1.5^{\circ} \leq \beta \leq 4.1^{\circ}\right)$ except the Nankai and Aleutian wedges where basal tectonic erosion is suspected further back from the trench [Lallemand, 1992. Seven tapers representative of typical accretionary wedges form a cluster around the lower stability mean envelope. This probably means that their friction angles and pore fluid pressure ratios are similar. Small lateral variations are noted along the Lesser Antilles subduction zone (A1 to A5; Figure 7) despite the increasing size of the accretionary wedge from north to south due to the sediment input from the Orinoco river. At smaller wavelength $(20 \mathrm{~km}$ instead of $150 \mathrm{~km})$, we always observe very smooth topographic slopes $\left(0^{\circ} \leq \alpha \leq\right.$ $1.9^{\circ}$ ) along each of the five Lesser Antilles transects.

"Intermediate" and nonaccretionary wedges are scattered in regions of higher $\alpha$ and $\beta$, the largest tapers corresponding to nonaccretionary wedges. Most of them are located in the vicinity of the upper extensional envelope, two of them (I2 and 19) are clearly located in the mean stability field, and three of them (N3, N4 and N7) are located in the unstable extensional field. Such a dispersion can be interpreted in two ways. If we assume that characteristic parameters are similar in every subduction zone, then we can conclude that half of intermediate to nonaccretionary wedges are stable/passive when tectonic erosion occurs and half are characterized by extensional faulting. Alternatively, if we assume that the characteristic parameters of "intermediate" and nonaccretionary wedges are significantly different, then several stability envelopes can be adjusted to account for the observed tectonic regimes: compressional, stable or extensional (see Figure 4). Unless we obtain measurements of friction angles or pore fluid pressures in those areas, we can only conclude that tapers are large and very scattered.

The lateral variations of each taper among the five transects crossing the Japan Trench margin (I4 to I8; Figure 8) are significant but remain close to the upper stability field envelope. At smaller wavelength (10 km instead of $80 \mathrm{~km})$, we observe large variations of $\alpha\left(0.1^{\circ} \leq \alpha \leq 8.6^{\circ}\right)$ along each of the five Japanese transects, attesting either that characteristic parameters vary along a transect or that the wedges may be stable. This can be explained by the long history of tectonic erosion that shaped the Japan Trench margin during Neogene time, which was followed during Quaternary time by some accretion [von Huene et al., 1982; von Huene and Lallemand, 1990; Lallemand et al., 1992a]. Lateral variations from one transect to another are of the same order of magnitude as variations along a single transect. We note that transect 17 , which was used as a reference profile for demonstrating tectonic erosion processes [e.g., von Huene and Culotta, 1989], can be distinguished from the other transects by a higher surface slope angle at the toe of the prism.

Similar remarks can be made concerning the five transects of the Tonga-northern Kermadec Trench margin (N2 to N6; Figure 9) but with a larger scattering of mean tapers, even greater when considering variations along each of them at smaller wavelength $\left(0.2^{\circ} \leq \alpha \leq 25.9^{\circ}\right.$ !). This very steep extreme surface slope was measured along a 4-km-long 


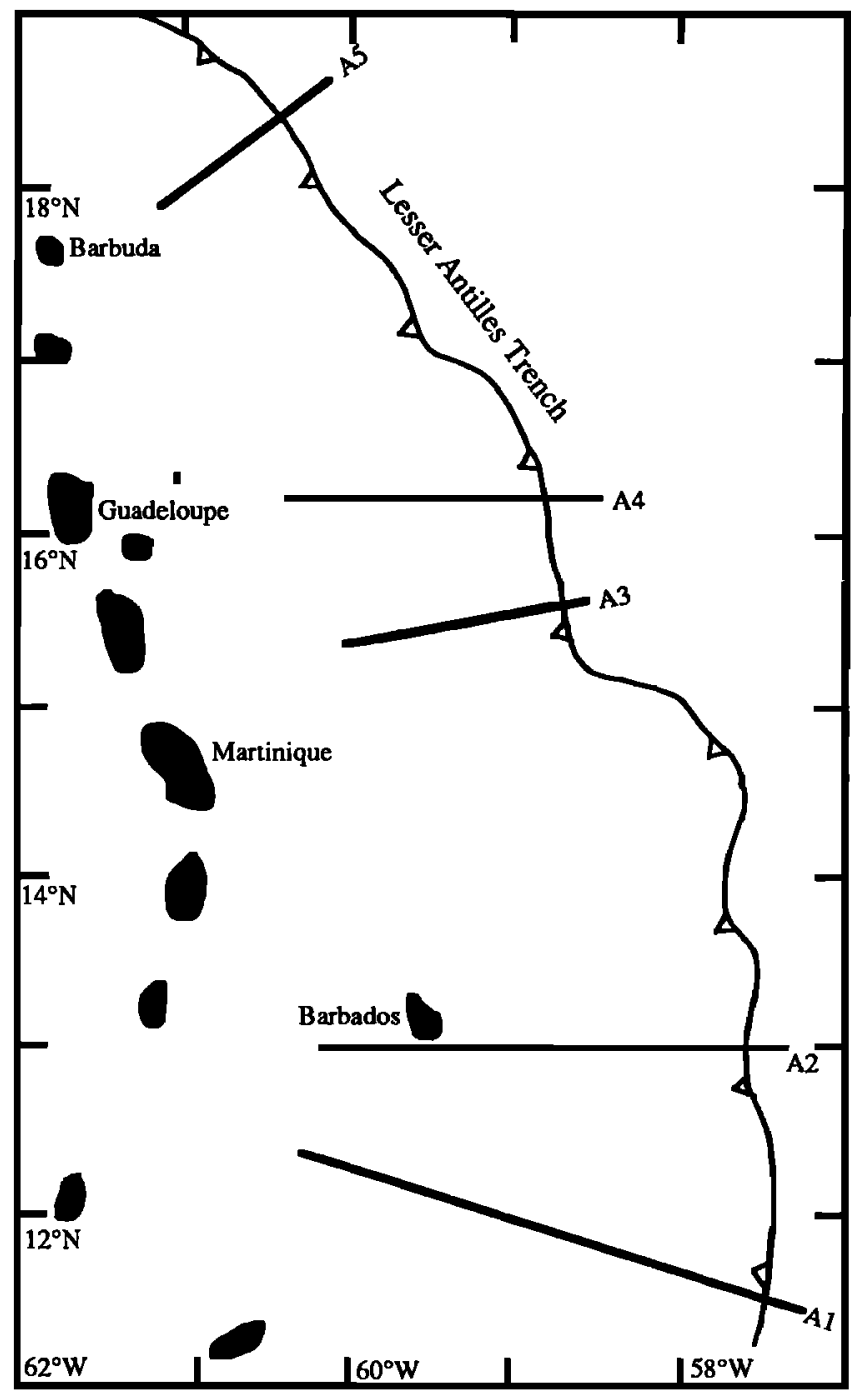

Figure 7. Location of the five transects off Lesser Antilles.

segment of transect N4. Again, it indicates either that characteristic parameters vary along a transect or that the wedge may be stable. The steepness of the surface slope for the two transects $\mathrm{N} 3$ and $\mathrm{N} 4$ is probably related to the recent subduction of the Louisville Ridge [Lallemand et al., 1992b]. Extensional faulting has been documented north of the collision zone [Pelletier and Dupont, 1990] and is in agreement with the tapers' distribution on the mean stability diagram (Figure 6). Pelletier and Dupont [1990] have shown that the tectonic regime in the Kermadec Trench changes near $32^{\circ} \mathrm{S}$ from erosion in the north to accretion in the south. We thus decided to classify the southern Kermadec transect I3 in the "intermediate" accretionary wedge group. The surface slope of this transect is far smoother than those of N2 to N6.

From the observed variations of 28 convergent margins, we conclude that margins characterized by large accretionary wedges are homogeneous regarding their small tapers (cluster of points on Figure 6). The location of the cluster along the lower stability mean envelope is compatible with the process of continuous frontal accretion. The wedges swing between a compressional tectonic regime and stability close to the critical taper. Surface slopes are generally smooth compared with other margins. On the other hand, nonaccretionary margins exhibit scattered and larger tapers with large variations in surface slope along one transect. This rough morphology may reflect some tectonic activity such as basal removal of upper plate material, which steepens the surface slope. Depending on the tectonic regime of such margins, deduced from seismic interpretations or diving observations, it is possible, for example, to provide some estimates of the fluid pressure ratio $\lambda$ within the wedge, making some basic assumptions (e.g., keeping the two other parameters $\mu$ and $\mu_{b}$ constant; insets of Figure 4). Increasing $\lambda$ narrows the stability field and consequently brings the compressional and extensional domains closer.

\section{Other variations of specific parameters}

In addition to the tapers, we compare the following parameters in Table 2: the trench sediment thickness $T_{p}$, the orthogonal convergence rate $v$, the vertical offset of oceanic faults $V_{0}$ and an estimate of the oceanic seafloor roughness along the 28 selected transects. We define an "oceanic seafloor roughness" coefficient $\left(R_{c}\right)$ which is a factor proportional to the total volume of oceanic positive and negative features such as grabens, ridges or seamounts within $200 \mathrm{~km}$ from the trench axis, integrated over the three sets of transects (Lesser Antilles, Japan and Tonga) and then normalized. Figure 10 summarizes the mean specific parameters $\left(\alpha, \beta, T_{t}, v, V_{o}, R_{c}\right)$ for each group of convergent margins. The product $T_{t} \times v$ corresponds to the "modern input sedimentary flux" (arbitrary unit in Table $2 ; 10^{-1} \mathrm{~km}^{2} / \mathrm{Ma}$ ). The correlation between the different groups of wedges for each specific parameter is

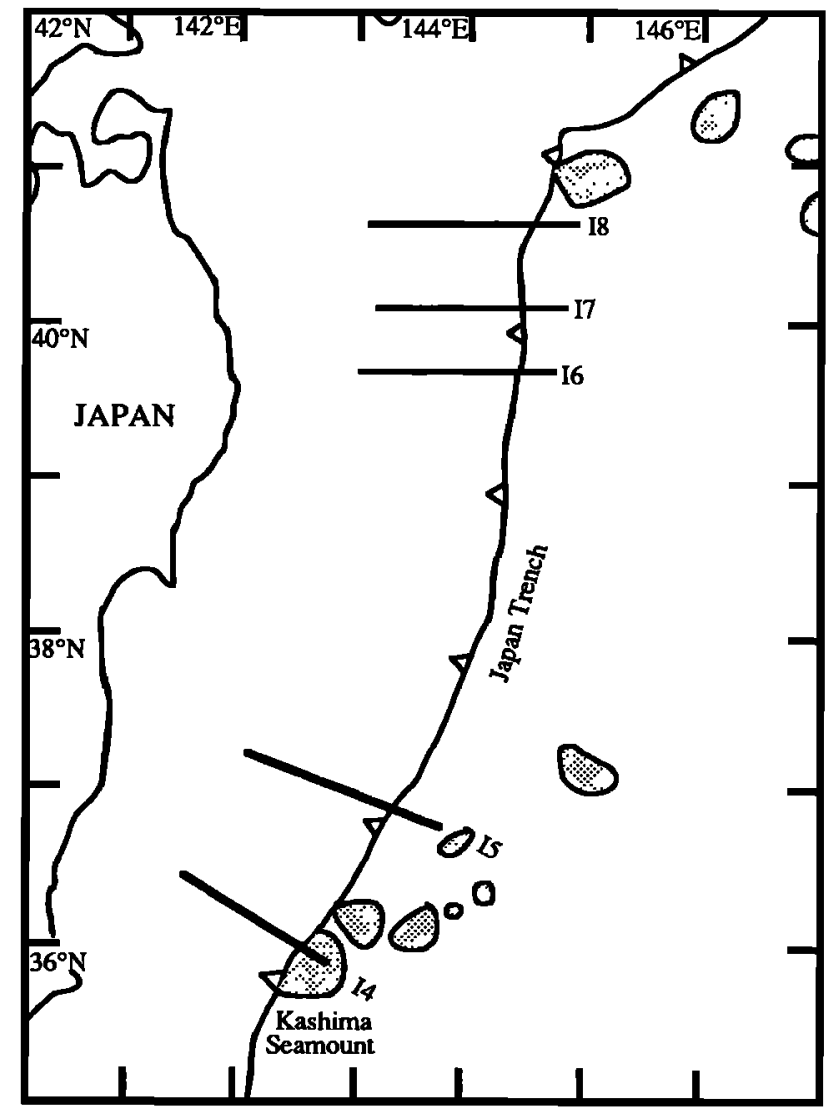

Figure 8. Location of the five transects off northeast Japan. 


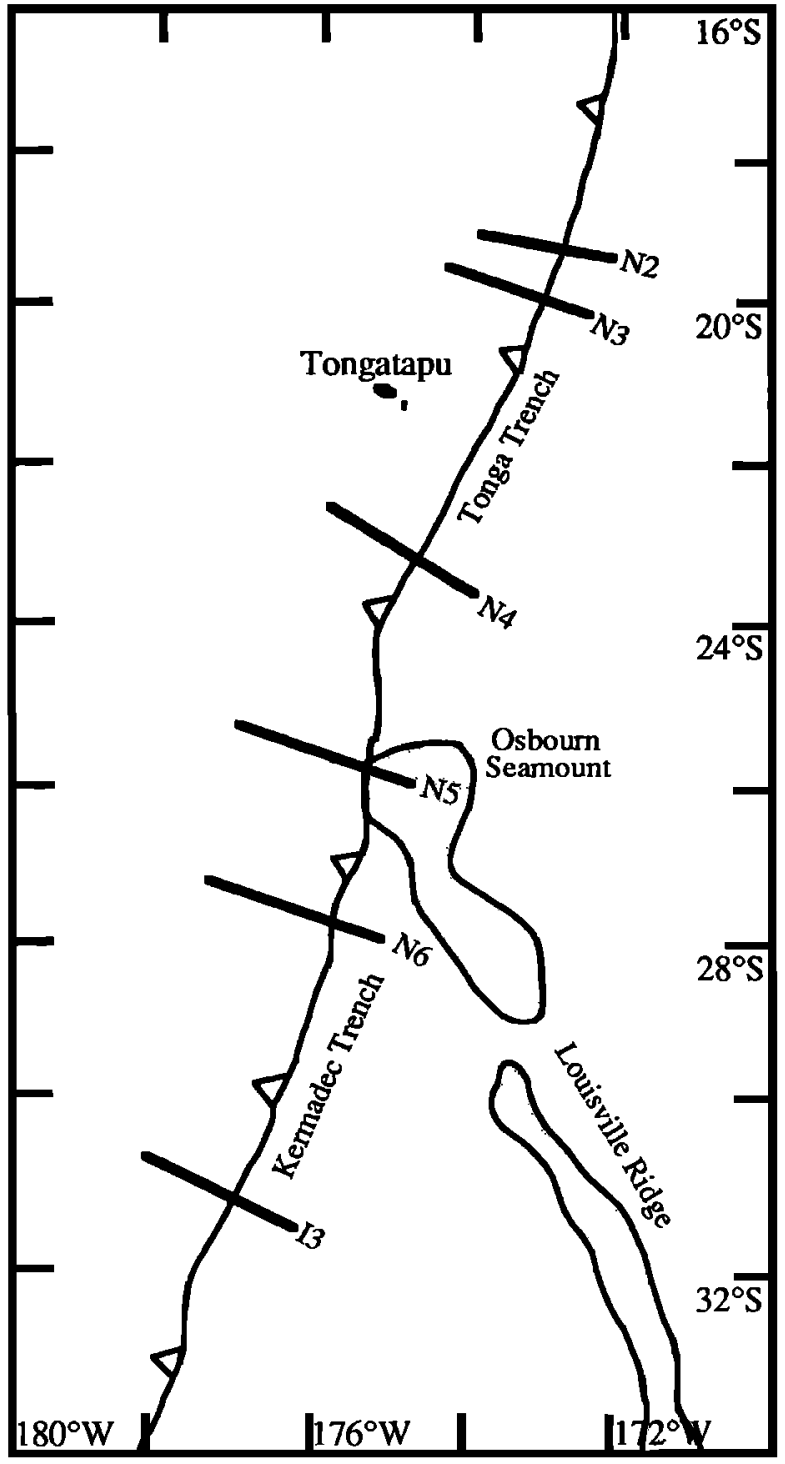

Figure 9. Location of the five transects off Tonga Islands and the one off Southern Kermadec Islands.

obvious, but chere is no clear correlation with $T_{1} \times v$. Typical accretionary wedges are characterized by hick trench sediment (average: $2.4 \mathrm{~km}$ ), low convergence rates (average: $3 \mathrm{~cm} / \mathrm{yr}$ ), almost no oceanic fault scarps and a small seafloor roughness coefficient. Non-accretionary wedges are characterized by thin trench sediment (average: $0.4 \mathrm{~km}$ ), high convergence rates (average $11.7 \mathrm{~cm} / \mathrm{yr}$ ), larger oceanic faults offsets $(0.7 \mathrm{~km}$ ) and a high seafloor roughness coefficient. In contrast, variations in input sediment budgets do not clearly correlate with any type of accretionary wedge.

These observations are compatible because low convergence rates allow greater trench deposit, assuming a constant trench sedimentation rate. Thick trench fill favors frontal accretion and a wide accretionary wedge (with a gentle surface slope) would deflect the subducting plate less than a margin characterized by a larger taper [Karig et al., 1976]. First, we can reasonably postulate that the type of the margin (i.e., accretionary or nonaccretionary) does not influence the convergence rate $v$ or the occurrence of seamounts and ridges on the oceanic plate $V_{0}$. Consequently, $v$ and $V_{0}$ both are good candidates as primary causes for frontal accretion or tectonic erosion. Second, we also observe good correlations between the type of the margin and two other parameters, the taper angle and the oceanic faults vertical offset. Thus we will try to clarify in this paper the type of interaction which accounts for these observations.

\section{Lessons From Sandbox Modeling}

Sandbox modeling is especially useful because we can measure directly the internal and basal friction angles as well as the step-up angles of faults. Furthermore, we can observe the dynamic evolution of the wedge and its internal deformation during experiments.

A glass-sided rectangular deformation box roughly reproduces the geometrical conditions and kinematics of a subduction zone. A polyvinyl chloride (PVC) medium which simulates the oceanic crust with its sedimentary cover is pulled at a constant rate. Sand units are progressively stacked against a rigid backstop, analogous to the island arc or continental basement against which sediments are accreted, to generate an accretionary prism. It was demonstrated by Malavieille et al. [1991] that a $30^{\circ} \pm 5^{\circ}$ dipping backthrust forms within the sand when the backstop inclination differs from this critical angle, which is close to the angle of friction of dry sand.

Isotropic models are built by forming horizontal sand layers, which include colored passive marker beds, on the moving plate. Dry quartz sand of aeolian origin, with a grain size of less than $300 \mu \mathrm{m}$, is used as an analogue for the oceanic sediments that make up accretionary wedges. The sand is essentially cohesionless and its deformation is timeindependent. This material satisfactorily simulates the brittle Coulomb behavior of shallow crustal rocks in laboratory experiments [e.g., Hubbert, 1937; Horsfield, 1977; Davis el al., 1983; Mc Clay and Ellis, 1987; Mandl, 1988; Mulugeta, 1988]. To a first approximation, we assume that sedimentary rocks of accretionary prisms behave as a single layer with an internal friction angle of $27 \pm 5^{\circ}$ (this study). Their cohesion, $\mathrm{C}_{0}$, is negligible compared with common shear stresses recorded in nature (about $10^{7}$ to $10^{8} \mathrm{~Pa}$ ). For the sand used in our experiments, cohesion $\mathrm{C}_{\mathrm{s}}=20 \mathrm{~Pa}$ is also negligible and the internal angle of friction, $\phi=30^{\circ}(\mu=\tan \phi=0.57)$, is similar. Thus the main difference with nature is the absence of pore fluid and hydrostatic pressures. The general Coulomb criterion for shear traction $\tau$ at failure becomes

$$
\tau=\mathrm{C}_{0}+\left(\sigma_{n}-P_{f}\right) \tan \phi
$$

where $\mathrm{C}_{0}$ is the cohesion, $\sigma_{n}$ is the normal stress, and $P_{f}$ is the fluid pressure ( $=0$ in sandbox experiments). Variables $\alpha^{*}$ and $\phi_{b}{ }^{*}$ simplify into $\alpha$ and $\phi_{b}$ in equations (2) and (3) because $\lambda=\lambda_{b}=0$ and $\rho_{w}=0$ too.

Density of sprinkled sand is about $1.7 \mathrm{~g} / \mathrm{cm}^{3}$ and the mean density of accreted rocks is about $2.3 \mathrm{~g} / \mathrm{cm}^{3}$. The deformation in these experiments occurs in a normal gravity field. Considering a mean cohesion of 10-15 $\mathrm{MPa}$ in incompletely lithified sediments [Hoshino et al., 1972] and a measured cohesion of 20-170 $\mathrm{Pa}$ at the interface between the dry sand and the various basal mediums, the scaling of the experiments [Hubbert, 1937; Ramberg, 1981] is such that $1 \mathrm{~cm}$ in the model is more or less equivalent to $1 \mathrm{~km}$ in nature. The scaling factor of $10^{5}$ is calculated by the ratio $(\mathrm{C} / \mathrm{pg})_{\text {in nature }} /(\mathrm{C} / \mathrm{pg})_{\text {in }}$ the experiments. 


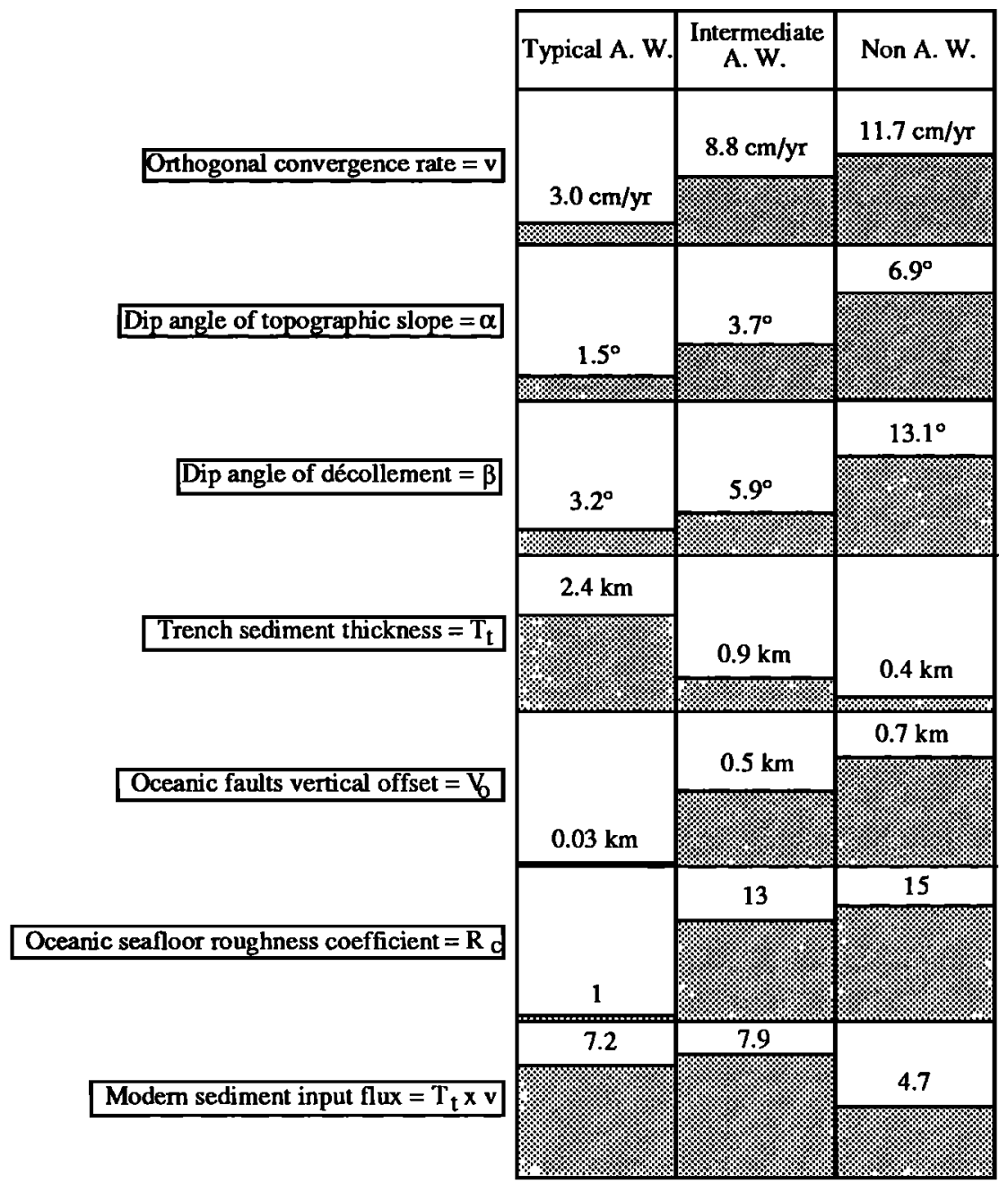

Mean values obtained from twenty eight transects

Figure 10. Mean parameters characterizing each group of wedges as described in Table 2. Abbreviation A. $W$. means accretionary wedges. See the text for further explanations.
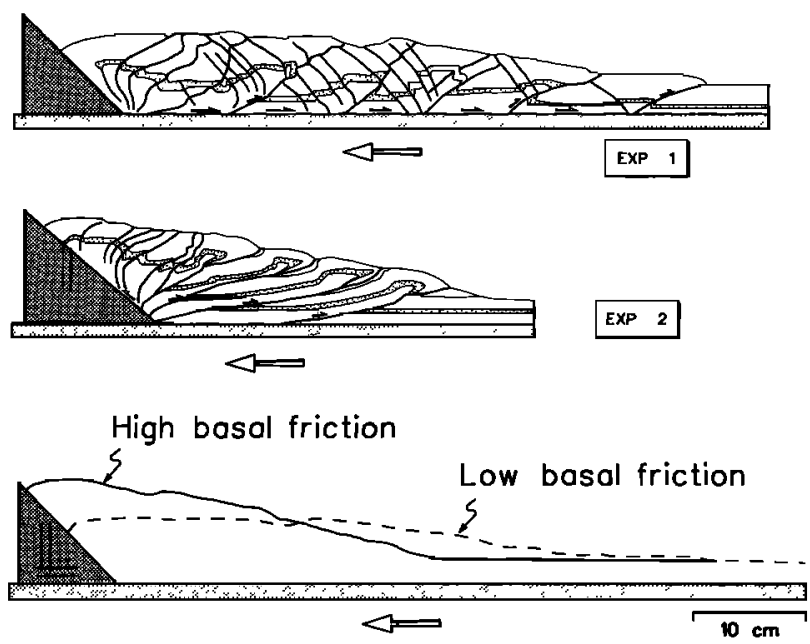

Figure 11. Two modeled critical wedges obtained after the same shortening and same incoming sand thickness but using two different values of basal friction. Variable $\mu_{b}=0.33$ in experiment 1 and 0.50 in experiment 2. For the same horizontal décollement, the topographic slope is steeper for a higher basal friction.
Five experiments have been conducted using the same apparatus and sand, but different boundary conditions. Several authors have discussed results from sandbox modeling when simulating an accretionary wedge [Davis et al., 1983; Dahlen et al., 1984; Malavieille, 1984; Mulugeta, 1988; Colletta et al., 1991; Huiqi et al., 1992; Malavieille et al., 1993]. We briefly illustrate this type of experiment and propose some simple mechanical explanations for the results. In contrast, experiments simulating the wedge deformation when ridge or seamount subduction occurs have not been intensively studied [Biagi, 1988; Malavieille et al., 1991; Robion, 1991; Lallemand et al., 1992b; Lallemand and Malavieille, 1992]. We examine in detail some of this second type of experiment.

\section{Mechanics of Accretionary Sand Wedges}

We have tested different values of basal friction for the same thickness of accreted sand. We have used for that purpose several basal media such as polished PVC which is characterized by a low coefficient of basal friction $\left(\mu_{b}=0.33\right.$ and $\left.C_{b}=170 \mathrm{~Pa}\right)$; mylar sheet $\left(\mu_{b}=0.42\right.$ and $\left.C_{b}=160 \mathrm{~Pa}\right)$ and two types of gummed paper which are characterized by higher 
coefficients of basal friction $\left(\mu_{b}=0.46-0.50\right.$ and $C_{b}=110$ $130 \mathrm{~Pa}$ ).

Figure 11 illustrates two wedges obtained after the same shortening and same incoming sand thickness but using two different values of basal friction. For the same horizontal décollement, the topographic slope is steeper for a higher basal friction. This is easily explained by Coulomb theory using equation (30) of Davis et al. [1983]:

$$
\alpha+\beta=\frac{\mu_{b}+\beta}{1+K}
$$

where the dimensionless integral $K$ is a function of $\mu$ and $\mu_{b}$, which is close to 1.8 according to the values obtained by numerical calculation with $\mu=0.57\left(\mathrm{~K}=1.9\right.$ for $\mu_{\mathrm{b}}=0.33$ and $K=1.65$ for $\mu_{b}=0.50$ ). This equation is apparently not correctly dimensioned, but this is because Davis et al. [1983] used the small-angle approximation in which $\sin \alpha \approx \alpha$ and $\sin \beta \approx \beta$. Variable $\beta=0$ in the experiments, so that $\alpha=\mu_{b} /(1+$ K). The predicted values of $\alpha=6.5^{\circ}$ and $10.8^{\circ}$, respectively, for the previous low and high coefficients of friction are close to the measured values of $6.5^{\circ}$ and $10^{\circ}$.

The style of deformation also differs when basal friction changes. For example, backthrusts are more abundant when the basal friction is low. The reason is that the $\sigma_{1}$ axis dips toward the foreland at an angle $\psi_{b}$ that increases with increasing coefficients of basal friction [Davis and Engelder, 1985]. When the basal friction is very low, $\psi_{\mathrm{b}}$ approaches zero. The potential slip planes are then almost symmetrical about the horizontal and backthrusts are thus common. When the basal friction is high, $\psi_{b}$ increases. The forward verging plane then dips at $\theta-\psi_{b}$ and the backward verging plane at $\theta$ $+\psi_{b}$, with $\theta=45^{\circ}-\phi / 2=15^{\circ}[$ Hafner, 1951]. The shallower dip may be favored because of bedding strength anisotropy [Davis and Engelder, 1985].

\section{Mechanics of Sand Wedges During Seamount/Ridge Subduction}

Tectonic erosion is a process which is very difficult to test using sandbox models because of the limited possibilities of experimental boundary conditions. On the other hand, it is easy to examine wedge deformation related to asperity subduction. This simple approach neglects factors such as sediment anisotropy or fluid pressure that strongly influence the process in nature, but we will see in the following section that the basic conclusions obtained by the experimental approach are consistent with the natural observations. We use these experiments as simple illustrations of natural processes.

Three experiments have been conducted with $2 \mathrm{~cm}$ of continuous accretion of sand above a low frictional medium $\left(\mu_{b}\right.$ $=0.33$ ). The accretionary wedges were first built and then indented by various positive features, a smooth truncated cone simulating a seamount, a rigid body normal to the sidewalls with a rounded cross section simulating an aseismic ridge and a seaward vergent basement slice also normal to the sidewalls simulating an active basement thrust slice. The first experiment (seamount subduction) is illustrated in Figure 12 [Biagi, 1988]. The two other experiments (ridge and slice subduction) are illustrated in Figure 13 [Lallemand et al., 1992b].
The first effects of asperity subduction are the indentation of the wedge and consequent active compression/shortening in front of the indenter, the uplift of the wedge above the subducting feature and the blocking of the basal décollement propagation. The second effect which is of great interest when looking at potential tectonic erosion is the path of the décollement in the vicinity of the asperity. The asperity is fixed on the basal medium, so that the décollement is necessarily forced upwards within the sand. This phenomenon was described at the Tonga Trench by Ballance et al. [1989] as "tunnelling process."

We observe on cross section 4 (Figure 12) that a sand wedge is isolated in front of the indenter, which is limited arcward by a $30^{\circ}$ dipping slip plane ( $\sigma_{1}$ is supposed to be horizontal). The slip plane acts as a ramp while the new décollement propagates forward and the wedge is passively pushed arcward by the subducting seamount. A similar sand wedge is not formed in the ridge experiment (Figure 13) because its flank already dips at about $30^{\circ}$. Neither does it appear in the slice experiment (Figure 13) because the arcward flank of the slice dips only a few degrees and the décollement just follows the basal plane of weakness.

From the top of the asperity (Figures 12 and 13), a new décollement forms subparallel to the basal plate because it is inherited from the first stages of asperity subduction. We noted that this newly formed "décollement" (called the "top décollement" in the following discussion) was forced to propagate arcward at the same rate as the asperity subduction. Its level within the sand wedge thus appears to be controlled by the height of the asperity before subduction of the basement slice (Figure 13), except in the slice experiment, where the " top décollement" is initiated as a thrust dipping about $25^{\circ}$.

We observe in experiment 5 (Figure 13) that the top décollement becomes inactive after about $10 \mathrm{~cm}$ of slice subduction [Lallemand et al., 1992b] as evidenced by the generation of a new accretionary wedge at the toe of the older deformed wedge. As long as the top décollement is active, the entire thickness of incoming sand is underthrusted beneath the deformed wedge. As soon as the décollement jumps from a high level in the wedge to the basal plane of least mechanical resistance, a new thrust appears within the incoming sand unit and generates a new accretionary wedge. The path of the basal décollement shields a domain where sand is trapped and then subducted in the wake of the asperity.

The jump of the décollement to the bottom of the wedge occurs only in experiment 5 , probably because the height of the basement asperity was less than in the two other experiments and because of a sufficient amount of penetration (subduction). One may argue that the décollement uses the least energetic path, but the complexity of the system makes estimates of energy requirements overcomplicated. Such an energetic approach has been already discussed [Lallemand, 1992; Schnürle, 1994]. Further experiments need to be performed in order to quantify the amount of penetration which is enough, according to a given height of asperity, to produce such a jump.

\section{Summary of the Results of Experimental Modeling}

Five experiments were performed to illustrate the deformation of a sand wedge when accretion and asperity subduction occur. We conclude that the following: 

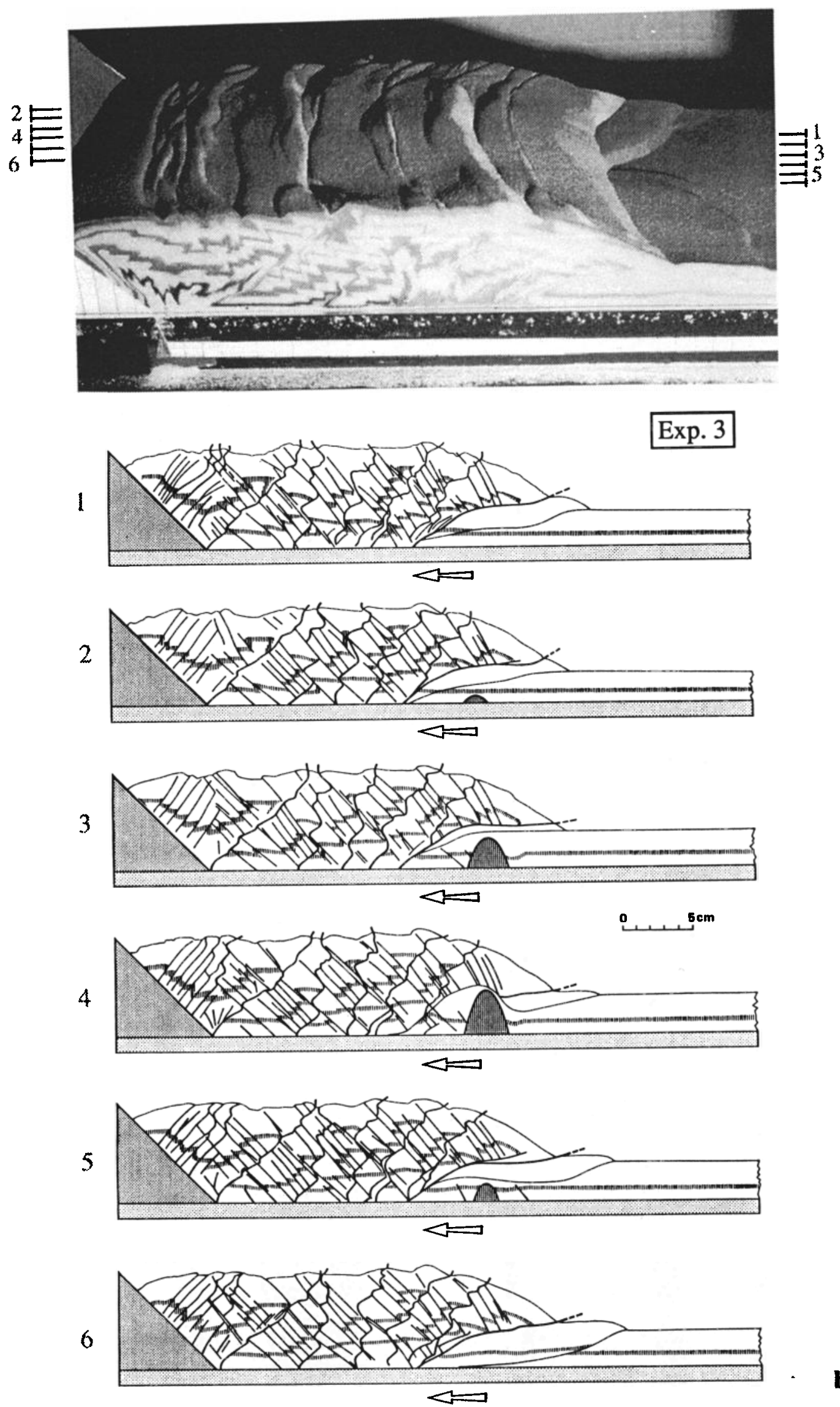

Figure 12. (a) Perspective view of the final stage of the seamount subduction experiment 3 . Note the two lobes that develop in the wake of the subducting seamount involving the incoming sand layer. These reflect the blocking of the forward propagation of the décollement against the seamount. (b) Interpreted cross sections of the final stage of seamount subduction experiment after the model had been cut and photographed at $2 \mathrm{~cm}$ intervals to observe lateral variations of the internal deformation. Note the drastic shortening of the wedge in front of the indenter (seamount) and the lateral ramps which accomodate the development of the two lobes (frontal imbricates). 

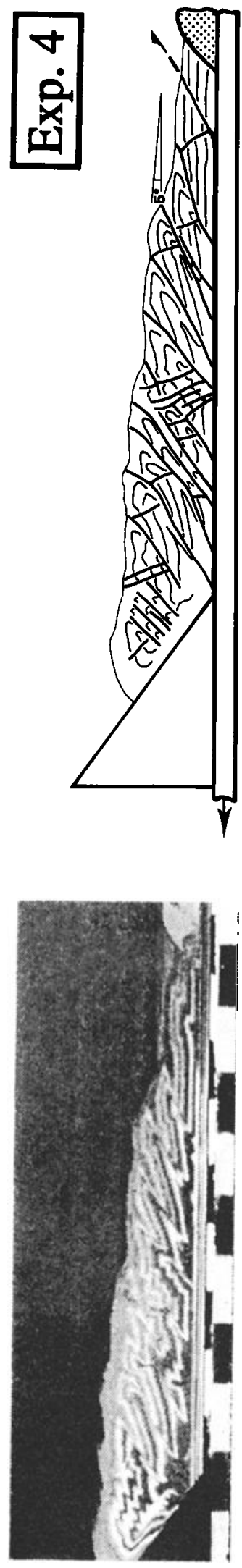
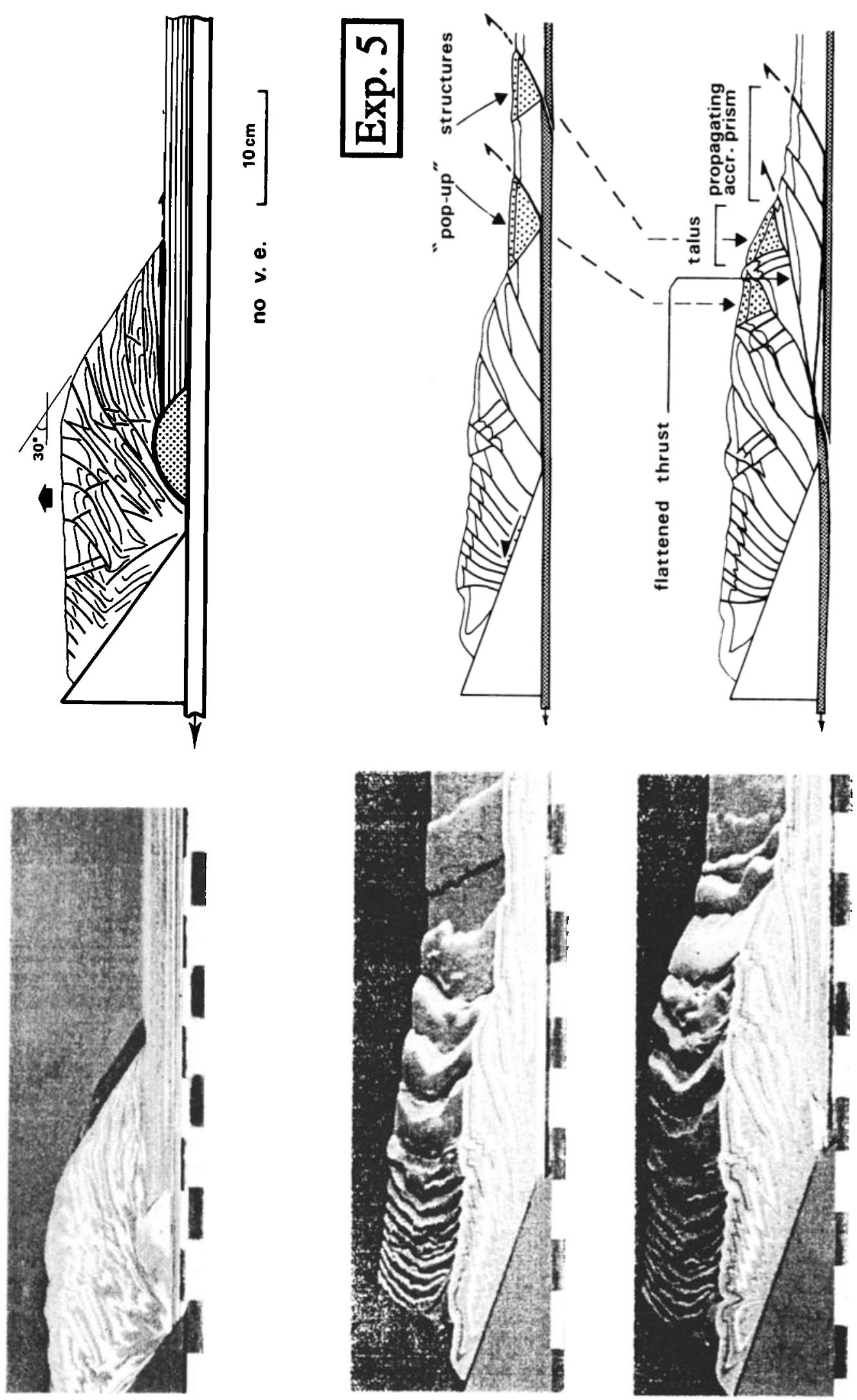

$\varangle 1 m$ 
1. Critical tapers stabilize along the lower stability field envelope when accretion occurs without asperity subduction (experiments 1 and 2). In contrast, tapers increase when asperity subduction occurs (experiments 3 to 5 ) in response to the higher basal friction (sand against sand) along the top décollement. The surface slope is locally overcritical $\left(\alpha=30^{\circ}\right.$ which is the angle of repose of sand) in response to the continuous removal of sand from the front of the wedge (tunneling effect). These experimental results are in good agreement with previous observations.

2. In the wake of a subducting asperity, a top décollement forms within the wedge at a height relative to the basal plate which is almost the same as the height of the asperity. The newly formed décollement is active over a large distance before it jumps back to the basal plate (arresting the tunneling effect). This distance seems to increase with the height of the asperity. This phenomenon generales a supercritical cliff at the front of the overriding wedge in response to continuous reworking of the frontal part of the wedge. Furthermore, the inactive flat top-décollement can be reactivated during compressional phases of accretion after the downward jump to the basal décollement.

3. After the downward jump of the décollement, some sand is trapped under the basal décollement (shielded domain) and dragged passively with the asperity. This process contributes to the erosion of the overriding wedge and to the dramatic wedge deformation which continues for a long time after penetration of the asperity.

\section{Mechanical Control of Accretion and Erosion: Natural Cases}

One of the basic observations in our experiments is that in order to have tectonic erosion, the décollement is required to migrate upwards within the wedge material. How, then, is the decollement forced upwards in both the natural and experimental examples? We suggest two possible explanations:

1. A subducting ridge, seamount or horst first forces the décollement to migrate upwards. Then, after a certain amount of convergence, the décollement jumps downward probably to a level of least mechanical resistance. The path of the final smoothed décollement isolates a shielded domain of rock which is dragged passively with the subducting feature.

2. There exists a level characterized by a lower effective friction higher in the wedge. Dahlen [1984] has shown that a decrease in $\mu_{b}$ will produce the same effect as an increase in $\lambda_{b}$ since they only occur in the combination $\mu_{b}\left(1-\lambda_{b}\right)$. Consequently, an upward migration of the décollement to a higher level will be possible if the frictional resistance is lower or the pore fluid pressure higher.

\section{Positive Feature Effects}

We are fully aware that the application of empirical laws deduced from experiments to natural cases is not rigorous, but these experiments provide realistic explanations of various observations. Figure 14 represents four examples of subducting seamounts and associated wedge deformation. It has been demonstrated by Lallemand et al. [1989] that the down-faulted part of the Kashima seamount, presently subducting in the Japan Trench, pushes forward a wedge of upper plate material. The step-up angle of the thrust that limits the sandwiched material is close to $30^{\circ}$. The Bougainville seamount in the New Hebrides Trench was also intensively surveyed. Two dives crossed the plate boundary showing that a wedge of material belonging both to the apron of the seamount and to the upper plate was pushed forward [Collot et al., 1992]. Using magnetic anomalies, a subducting seamount was detected at the junction between the Japan and Kuril Trenches. A gigantic scar reflects the collapse related to its recent subduction and the trace of the plate boundary can be followed $1.3 \mathrm{~km}$ above the trench floor at the level of a midslope terrace [Lallemand and Chamot-Rooke, 1986]. Finally, Ballance et al. [1989] have pointed out a subducting seamount: the Motuku Guyot just north of the Louisville Ridge in the Tonga Trench, using a multichannel seismic line. The presence of the Motuku Guyot is marked by a prominent reflecting horizon $10 \mathrm{~km}$ long and a high contrast in seismic velocities. The surface trace of the décollement can be followed 1 to $2 \mathrm{~km}$ above the trench floor in the vicinity of the subducting seamount.

Other examples of subducting seamounts are published in the literature, all showing significant deformation of the wedge both in front and in the wake of the indenter [e.g., Fryer and Smoot, 1985; Fryer and Hussong, 1985; Pontoise et al., 1986; Lonsdale, 1986, Lallemand and Le Pichon, 1987; Collot and Fisher, 1989; Lallemand et al., 1990].

Von Huene et al. [1994] published a Hydrosweep bathymetric map off Costa Rica where three stages of seamount subduction are beautifully documented. Figure 15 shows an extract of this map. The first stage (1 on Figure 15) is equivalent to the examples shown on Figure 14. It shows a gigantic scar in the wake of the subducted seamount without an accretionary wedge at its base, attesting that the level of the décollement is shallower than the trench seafloor (see the schematic cross section 1 on Figure 16). This first seamount has already undergone $20 \mathrm{~km}$ of subduction. The second stage is illustrated by another seamount ( 2 on Figure 15), which has already performed $30 \mathrm{~km}$ of subduction counted from the trench. A morphological scar attests to its subduction. At this stage, a new accretionary wedge formed in its wake. This demonstrates that the décollement jumped from a high level in the wedge to the bottom after between 20 and $30 \mathrm{~km}$ of

Figure 13. (a) Experiment 4 after Lallemand et al. [1992b]. The first illustrated stage is just before subduction of the ridge. The second and final stage illustrates the shortening and uplift of the wedge after ridge subduction. The active ("top") décollement parallels the basal plate and its level equals the height of the ridge. The subducting sand remains undeformed in the wake of the ridge. (b) Experiment 5 after Lallemand et al. [1992b]. The first illustrated stage corresponds to the initiation of the thrusting of the basement slice before its incorporation beneath the accetionary wedge. A pop-up is created within the sand just above the slice. The second and final stage shows the specific wedge morphology acquired during slice subduction. The wedge was first shortened and uplifted; a flat thrust corresponds to the propagation of the décollement during slice subduction and a new accretionary wedge develops. 

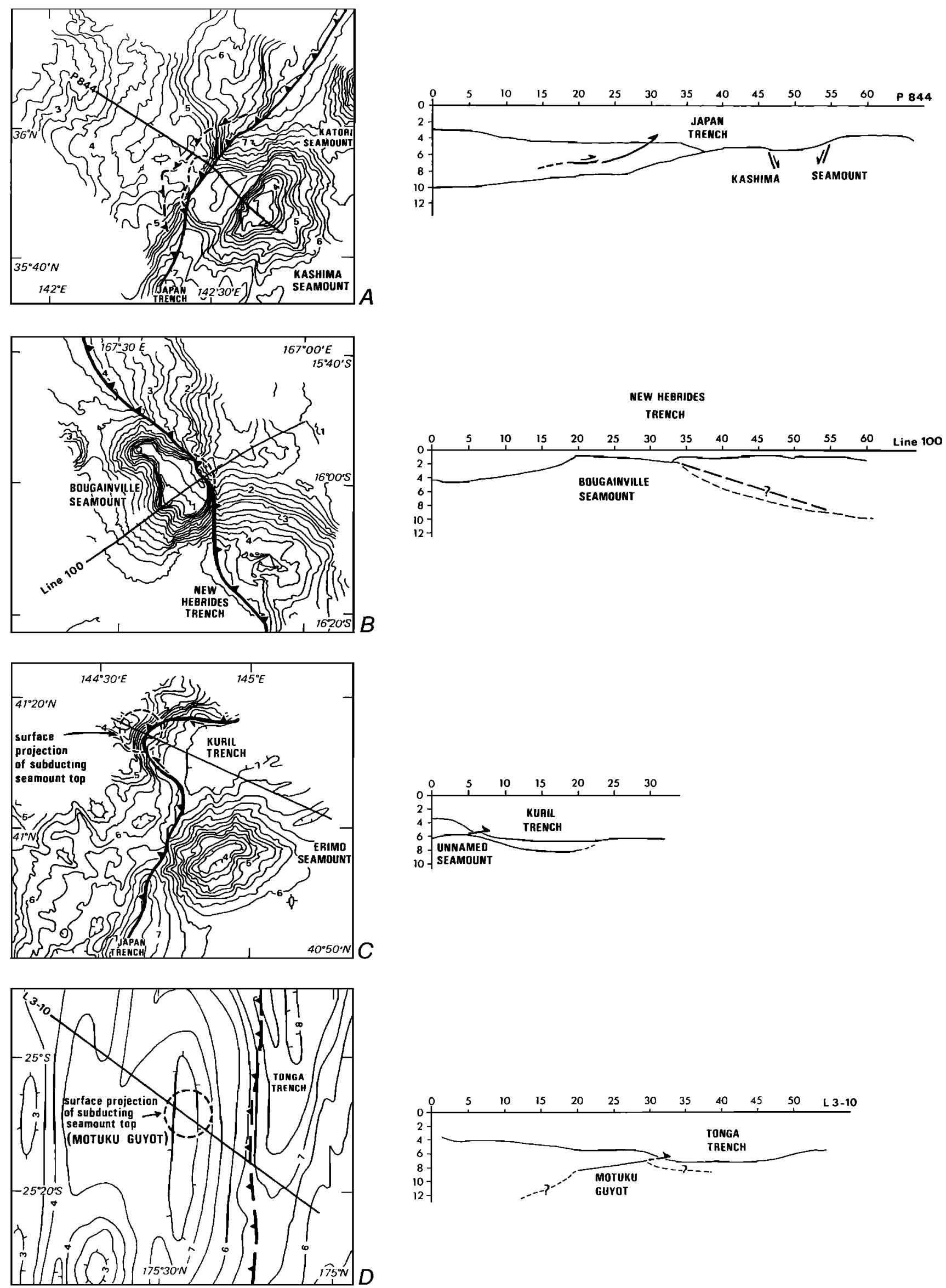


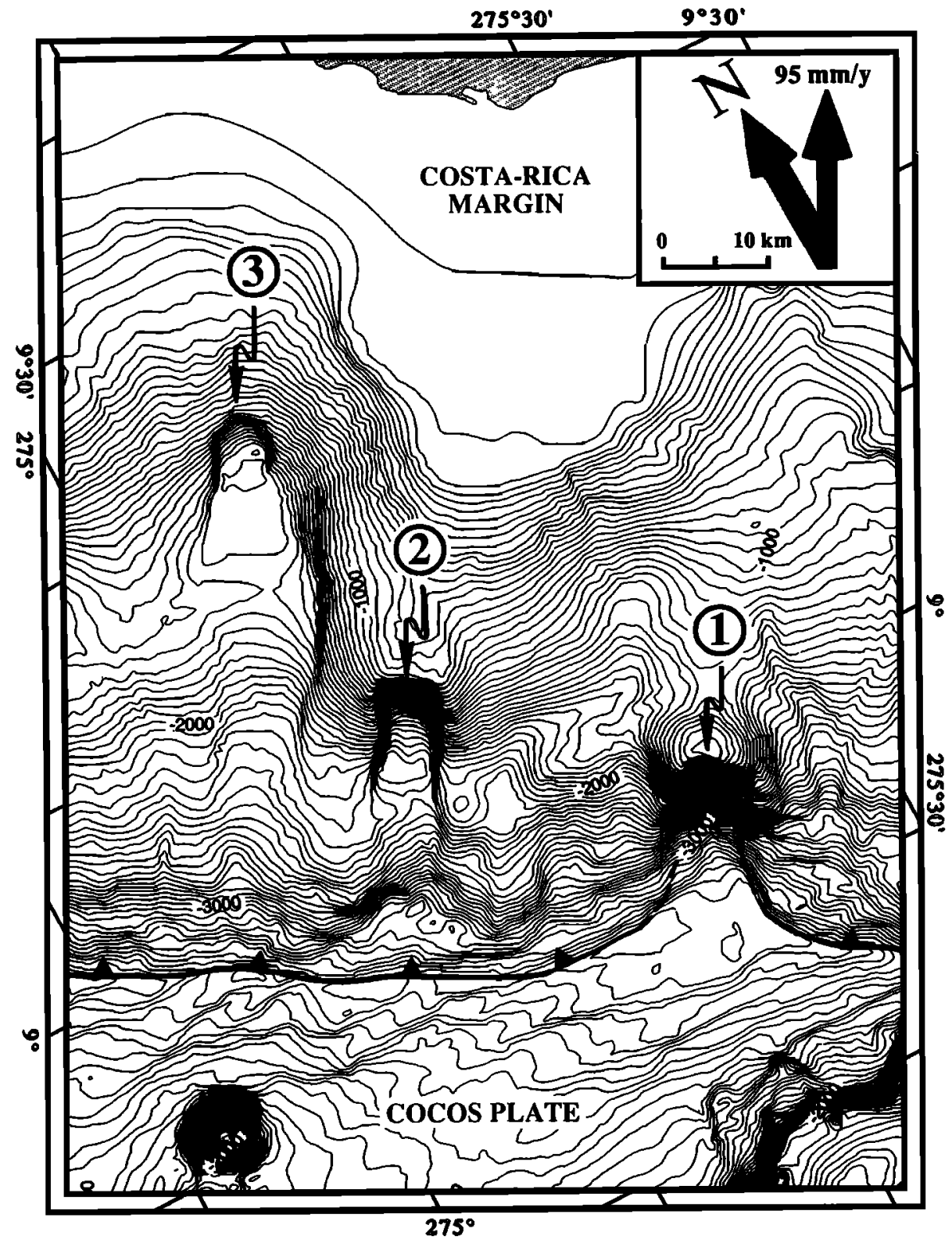

Flgure 15. Hydrosweep bathymetric map of the Costa Rican margin extracted from a larger map acquired during the R/V Sonne 76 cruise [von Huene et al., 1994]. Several seamounts on the Cocos plate are subducted beneath the margin. Their morphological traces, parallel to the plate convergence, are easily recognized on this map. Three stages of seamount subduction, labeled 1 to 3 , are schematically illustrated on cross sections in Figure 16.

subduction as illustrated on Figure 16. Finally, a third scar related to a subducted seamount is observed $50 \mathrm{~km}$ back from the trench where the margin's thickness exceeds $10 \mathrm{~km}$ ( 3 on Figure 15). This observation demonstrates that the seamount has not been offscraped, at least not until this depth of subduction ( 3 on Figure 16).

In addition to the upper plate material which is dragged downward with the seamounts during subduction, we have seen

Figure 14. Four examples of subducting seamounts and associated deformation of the wedge. Cross sections, without vertical exaggeration, are based on interpreted multichannel seismic lines except for the Kuril Trench where the location of the seamount is deduced from a magnetic model. The sections are located on the bathymetric maps to the left. The dashed circles superimposed on the bathymetric maps are the surface projection of the subducting seamounts top. The dashed and solid lines with black triangles represent the deformation front. Isobaths are each $250 \mathrm{~m}$ except for the Tonga Trench box where they are at $500 \mathrm{~m}$. The Japan Trench example (Figure 14a) is after Lallemand et al. [1989]. The New Hebrides example (Figure 14b) is after Fisher et al. [1991] and Collot et al. [1992]. The Kuril Trench example (Figure 14c) is after Lallemand and Chamot-Rooke [1986] and Cadet et al. [1985]. The Tonga Trench example (Figure 14d) is after Ballance et al. [1989] and Gnibidenko et al. [1985]. 


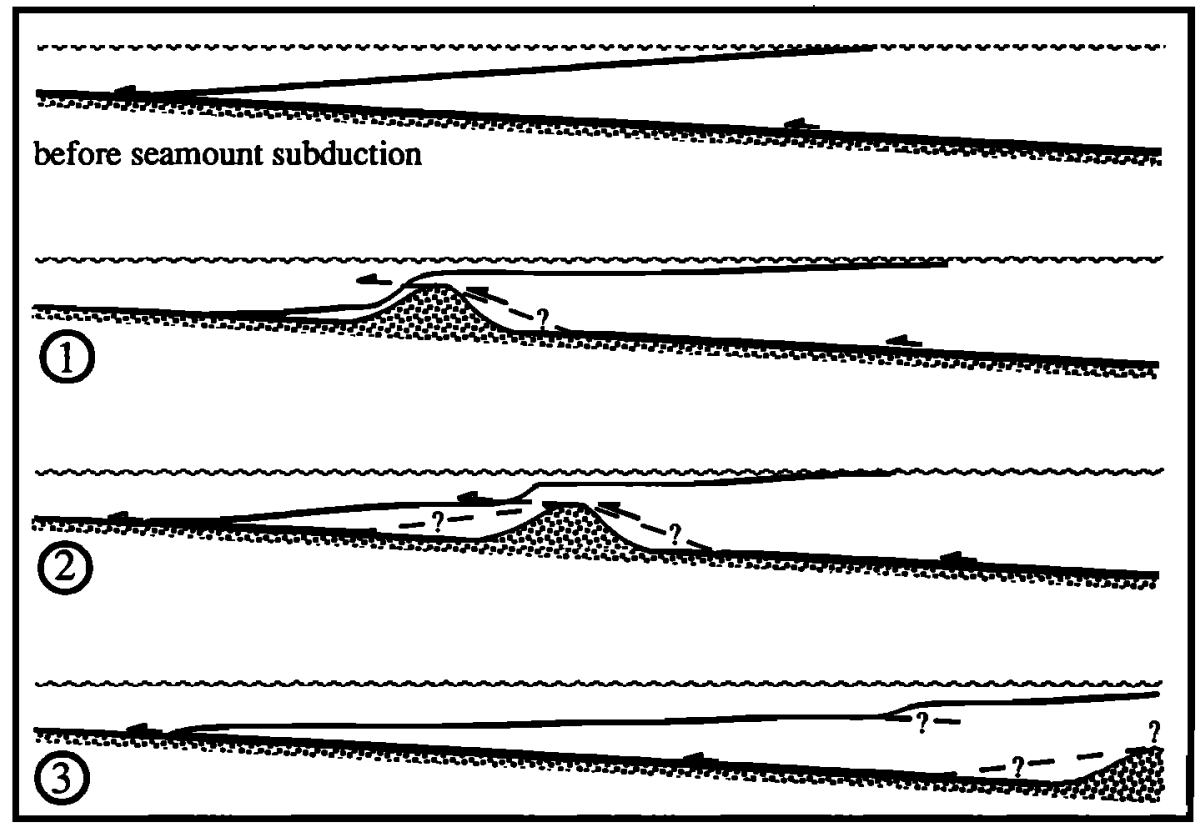

Figure 16. Schematic cross sections without vertical exaggeration of three stages of seamount subduction based on both morphological observations (Figure 15) and sandbox modeling results. The first stage before seamount subduction corresponds to the area located between seamount 1 and 2 on Figure 15.

that a great thickness of frontal upper plate material is passively transported in the wake of the trailing flank of the seamounts over several tens of kilometers. This phenomenon contributes to the oversteepening of the topographic slope especially at the toe of the wedges as observed along the previously described nonaccretionary wedges and most of the intermediate wedges (Figure 6). Some scars may reflect the emergence of presently inactive ancient "top décollements" (Figures 16 - number 3 - and 17). Such a prominent reflection paralleling the subducting plate and emerging at the base of a scarp is observed, for example, in the northern Japan Trench $3.5 \mathrm{~km}$ above the present décollement [von Huene and Culotta, 1989].

Figure 10 also shows that nonaccretionary wedges are characterized by a high amplitude of horsts and grabens. Considering the former discussion, it seems logical that the horsts behave like any other positive oceanic features. Their flanks are even steeper than those of seamounts or ridges, so that the slumped masses from the toe of the wedge and/or the trench fill (depending on the trench sedimentation rate) are easily trapped in the grabens and passively dragged with the subducting plate (Figure 17). This process is clearly imaged seismically in the northern Japan Trench [von Huene and Culotta, 1989], the Kurile Trench (P. Schnurle et al., Tectonic regime of southern Kurile Trench as revealed by multichannel seismic lines, submitted to Tectonophysics, 1994), the Tonga Trench [Ballance et al., 1989] and the Peru and New Hebrides Trenches [von Huene, 1986].

\section{Lower Effective Basal Friction Higher in the Wedge?}

Along nonaccretionary or intermediate margins such as Japan, fragmentation by hydrofracturing of the upper plate was invoked by von Huene and Lee [1983] and Plalt [1990]. Rock at the base of the upper plate may disaggregate as overpressured pore fluid invades and permeates through fractures [von Huene, 1984; von Huene and Lallemand, 1990], hence the level of maximum pore fluid pressure will move up through the wedge. Moore [1989] noted that with high rates of underthrusting, as along nonaccretionary wedges, sediment descending beneath the décollement zone is probably buried faster than it can dewater. From Table 2 we observe that the critical convergence rate which marks the occurrence of accretion is $6 \pm 1 \mathrm{~cm} / \mathrm{yr}$. For fast convergence rates, the process of upward migration of the décollement occurs progressively beneath the part of the wedge which is underthrusted by overpressured sediments, in other words, mainly the frontal part of the wedge [Platt, 1990] (Figure 17). Also, the average porosity of a thick section of incoming sediment is less than for a thin section (because of compaction). Consequently, the fluid potential will be higher in regions characterized by thin trench sediment/fast convergence rates, i.e., nonaccretionary and intermediate margins (Figure 10). This explanation is in agreement with the Coulomb wedge model, because the low taper predicted by the model when the basal friction is low is only valid when frontal accretion is active. The difference here is that basal and frontal removal occurs instead of frontal accretion. As a consequence, the taper adjusts itself to the downward flux of material, with respect to the Coulomb wedge model, to become either stable or even overcritical (Figure 6).

\section{Conclusions}

\section{Possible Causes for Frontal Accretion}

We have pointed out in this paper that typical accretionary wedges are characterized by a low convergence rate, a thick trench sediment thickness, a low taper and a relatively smooth subducting seafloor (Figure 10). Consequently, we conclude. to a first approximation, that a low convergence rate allows the deposition of a thick trench fill, which nourishes the 

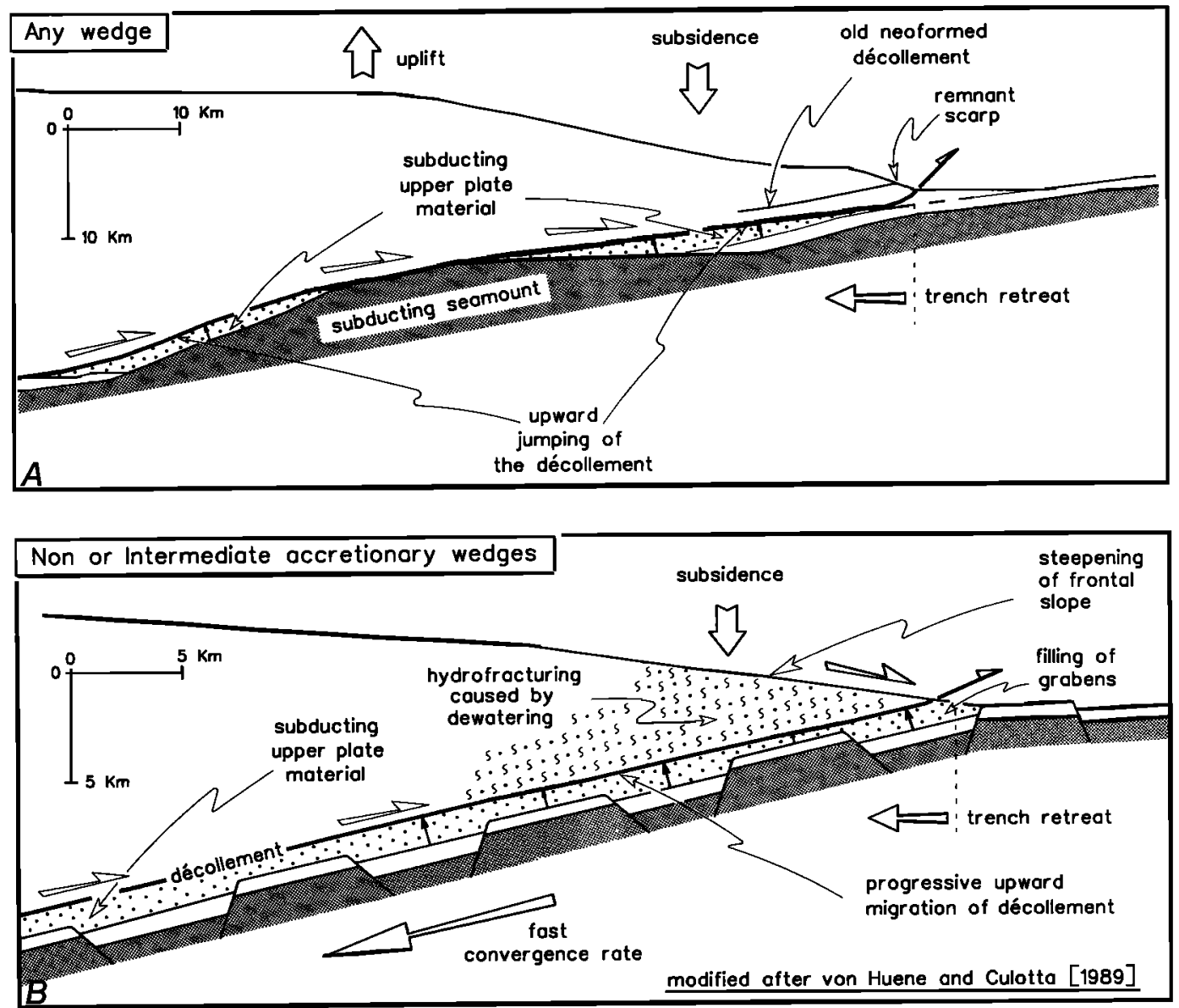

Figure 17. Sketches showing mechanisms of tectonic erosion along convergent margins. (a) A subducted positive feature is responsible for the dragging of upper plate material (dotted area). This situation may occur along any type of wedge. (b) This figure was modified after von Huene and Culotta [1939]. Horst and graben structures are subducting as happens generally along nonaccretionary or intermediate accretionary wedges. Grabens trap upper plate material slumped from the front of the wedge. The fast convergence rate, generally typical of nonaccretionary or intermediate accretionary wedges, is responsible for a delay in dewatering of underthrusted sediment and thus favors the upward migration of the décollement. Again, the dotted area corresponds to the removal of upper plate material.

accretionary wedge by partitioning of sediment at some level within the trench fill. Many authors have already described this mechanism of sediment partitioning [e.g., Le Pichon and Henry, 1992]. The low taper is purely a consequence of continuous frontal accretion maintaining the taper at the undercritical limit with respect to the local characteristic parameters (lower envelope on Figures 4 and 6). However, the existence of accretion does not exclude erosional processes being active as suggested by Le Pichon and Henry [1992]. Several examples, especially from "intermediate accretionary wedges" (northem Japan and Peru, for example), illustrate concomitant frontal accretion and basal tectonic erosion.

\section{Possible Causes for Frontal and Basal Tectonic Erosion}

Figure 18 suggests possible mechanisms of tectonic erosion and interactions between the various parameters. It accounts for the observations made both on the studied transects and from the experiments.

The first and most simple cause of tectonic erosion is, without doubt, the subduction of oceanic features, which drag upper plate material within grabens or in the vicinity of seamounts and ridges. The best example is probably the Tonga trench which shortened by about $100 \mathrm{~km}$ in the wake of the subducted part of the Louisville ridge [Pelletier and Dupont, 1990; Lallemand et al., 1992b]. This erosional process related to subducting seamounts and ridges is, a priori, independent of the convergence rate, hence of the type of margin. A fast convergence rate will just accelerate this type of erosional process. This is less obvious when considering the grabens, as shown on Figure 18.

The second cause is probably the convergence rate driving two possible mechanisms that produce hydrofracturing of the upper plate material by overpressuring (Figure 10). First, a convergence rate faster than the dewatering rate of subducted sediment would produce overpressuring which may lead to some form of sediment stoping. Second, a fast convergence rate does not allow the deposition of a thick trench fill because of time considerations. Because of a low degree of compaction, the thin section of trench sediment is characterized by a high porosity, hence a high fluid content, which results in overpressuring along the décollement.

We also suggest that tectonic erosion processes become self-maintained after they are active for a sufficient time. We 


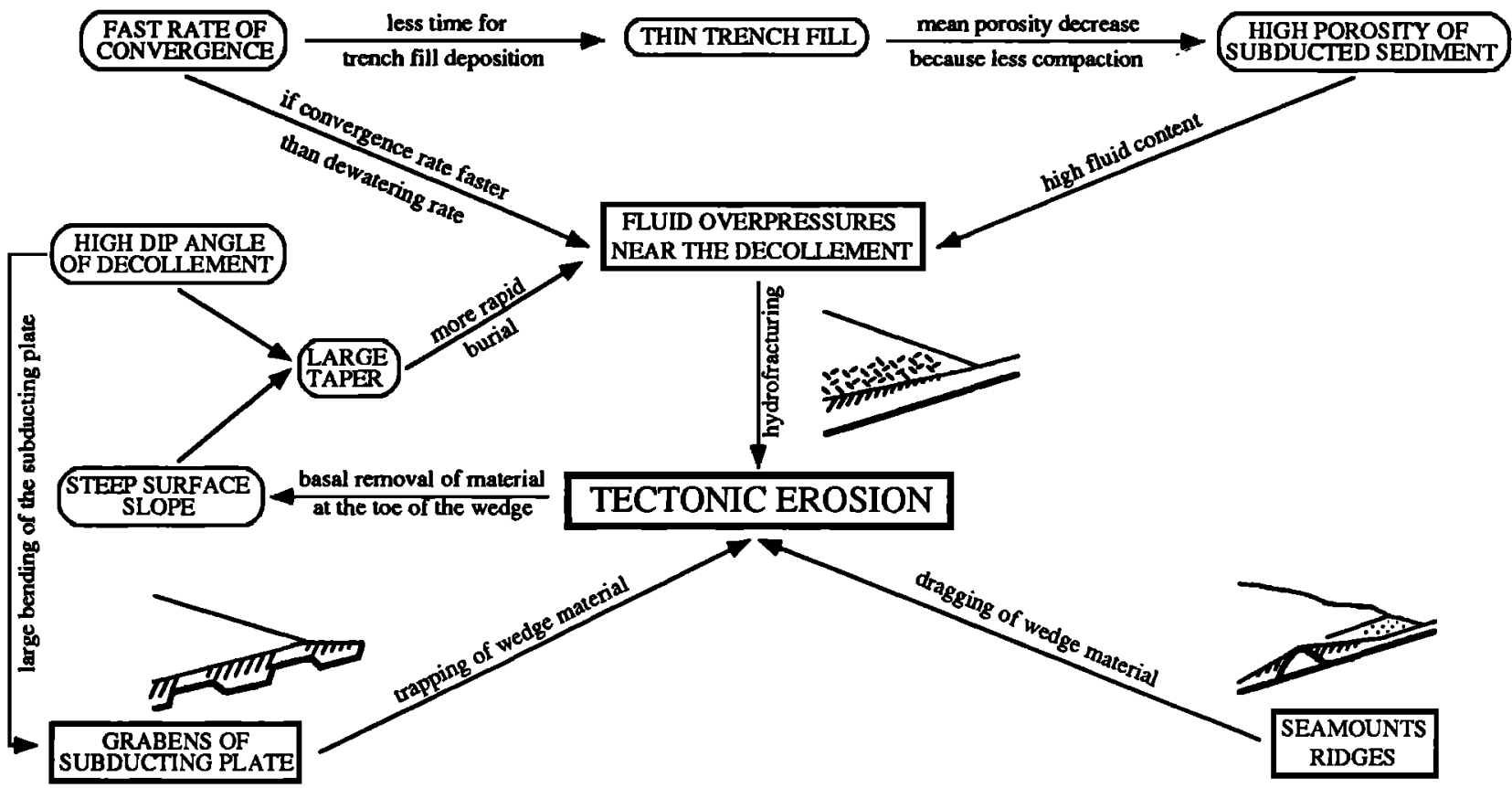

Figure 18. Diagram summarizing the various interactions between several parameters which lead to tectonic erosion [after Lallemand, 1992]. See the text for further details.

observe (see Table 2, for example) that nonaccretionary margins are characterized by a high dip angle of their decollement producing an increase of the amplitude of the outer bulge and thus a larger bending of the subducting plate before it enters the subduction zone. This generates normal faulting in the upper part of the oceanic lithosphere, hence horsts and grabens, which contribute to the process of erosion as described earlier. Because of the continuous basal removal of material at the toe of the wedge, the surface slope also steepens. A second consequence will be the increase of the taper, so that the subducted sediment will be buried more rapidly beneath an increasing pile of upper plate material. Last, it produces fluid overpressures within the subducted sequence of sediment and hydrofracturing.

If the self-maintenance of sufficiently mature erosional margins is real, then one could expect to find margins characterized by a long history of continuous removal of upper plate material. Such subduction zones may exist along the IzuBonin and Mariana trenches [Lallemand, 1992]. Arresting this process of erosion would probably require a long period of low convergence rate.

Conditions for tectonic erosion are accumulating along the Tonga Trench because this subduction zone records the highest known convergence rate, the highest of Iset of oceanic normal faults and because the Louisville Ridge was recently caught up in the subduction zone. It is therefore not surprising that the Tonga margin is typical of an erosional margin and that a great amount of upper plate material has been removed [Pelletier and Dupont, 1990; Ballance et al., 1989; Lallemand et al., 1992b].

Acknowledgments. Numerous discussions with Dan Davis, Roland von Huene, Xavier Le Pichon, Claude Rangin, Manuel Pubellier, Sylvain Calassou and Philippe Robion allowed us to improve earlier versions of the manuscript. JeanFrançois Brouillet and André Berthet helped us to draw some of the figures. This paper was first submitted in June 1992. It benefited from three constructive reviews from John Platt, M.M.P. Bott and an anonymous reviewer. Contribution CNRS-INSU-DBT 661.

\section{References}

Addicott, W.O., and P.W. Richards, Plate-tectonic map of the Circum-Pacific region, southwest quadrant, scale 1:10,000,000, Circum-Pac. Counc. for Energy and Miner. Resour., Am. Assoc. of Pet. Geol., Houston, Tex., 1981.

Aubouin, J., et al., Leg 84 of the Deep Sea Drilling Project, Subduction without accretion: Middle America Trench off Guatemala, Nature, 297, 458-460, 1982.

Ballance, P. F., D. W. Scholl, T. L. Vallier, A. J. Stevenson, H. Ryan, and R. H. Herzer, Subduction of a late Cretaceous seamount of the Louisville Ridge at the Tonga Trench: A model of normal and accelerated tectonic erosion, Tectonics, 8, 5, 953-962, 1989.

Biagi, R., Géométrie et cinématique des prismes d'accrétion sédimentaires: Modélisation analogique, Mém. $D E A$, Montpellier Univ., Montpellier, France, 1988.

Byerlee, J., Friction of rocks, Pure Appl. Geophys., 116, 615626, 1978.

Cadet, J.-P., et al., De la fosse du Japon à la fosse des Kouriles: Premiers résultats de la campagne océanographique francojaponaise Kaïko (Leg III), C. R. Acad. Sci. Paris, 301, 287-296, 1985.

Chapple, W.M., Mechanics of thin-skinned fold-and-thrust belts, Geol. Soc. Am. Bull., 89, 1189-1198, 1978.

Coletta, B., J. Letouzey, R. Pinedo, J.-F. Ballard, and P. Balé, Computerized $\mathrm{X}$-ray tomography analysis of sandbox models: Examples of thin-skinned thrust systems, Geology, 19, 1063-1067, 1991.

Collot, J.-Y., and M. A. Fisher, Formation of forearc basins by collision between seamounts and accretionary wedges: An example from the New Hebrides island arc, Geology, 17, 930-934, 1989.

Collot, J.-Y., S. E. Lallemand, B. Pelletier, J.-P. Eissen, G. Glaçon, M. A. Fisher, H. G. Greene, J. Boulin, J. Daniel, 
and M. Monzier, Geology of the d'Entrecasteaux-New Hebrides arc collision zone: Results from a deep submersible survey, Tectonophysics, 212, 213-241, 1992.

Cooper, P., and B. Taylor, Seismicity and focal mechanisms at the New Britain trench related to deformation of the lithosphere, Tectonophysics, 164, 25-40, 1989.

Dahlen, F. A., Non-cohesive critical Coulomb wedges: An exact solution, J. Geophys. Res., 89, 10125-10133, 1984.

Dahlen, F. A., J. Suppe, and D. M. Davis, Mechanics of foldand-thrust belts and accretionary wedges: Cohesive Coulomb theory, J. Geophys. Res., 89, 10087-10101, 1984.

Davey, F.J., K. Lewis, J.R. Childs, and M.A. Hampton, Convergent margin off east coast of North Island, New Zealand, Parts I and II, in Seismic Images of Modem Convergent Margins Tectonic Structure, edited by R. von Huene, AAPG Stud. Geol., 26, 49-53, 1986.

Davis, D., and T. Engelder, The role of salt in fold-and-thrust belts, Tectonophysics, 119, 67-88, 1985.

Davis, D. M., and R. von Huene, Inferences on sediment strength and fault friction from structures at the Aleutian Trench, Geology, 15, 517-522, 1987.

Davis, D., J. Suppe, and F. A. Dahlen, Mechanics of fold-andthrust belts and accretionary wedges, J. Geophys. Res., 88, 1153-1172, 1983.

Fisher, M. A., Tectonic processes at the collision of the d'Entrecasteaux Zone and the New Hebrides island arc, $J$. Geophys. Res., 91, 10470-10486, 1986.

Fisher, M. A., and H. G. Greene, The New Hebrides Trench, Lines 1 and 12, in Seismic Images of Modern Convergent Margins Tectonic Structure, edited by $\mathrm{R}$. von Huene, $A A P G$ Stud. Geol., 26, 43-48, 1986.

Fisher, M. A., J.-Y. Collot, and E. L. Geist, Structure of the collision zone between Bougainville Guyot and the accretion wedge of the New Hebrides island arc, Southwest Pacific, Tectonics, 10, 887-903, 1991.

Fryer, P., and D.M. Hussong, Seamarc II studies of subducting seamounts, in Formation of Active Ocean Margins, edited by N. Nasu et al., pp. 291-306, TERRAPUB, Tokyo, 1985.

Fryer, P., and N. C. Smoot, Processes of seamount subduction in the Mariana and Izu-Bonin Trenches, Mar. Geol., 64, $77-90,1985$.

Gnibidenko, H. S., G. I. Anosov, V. V. Argentov, and I. K. Pushchin, Tectonics of the Tonga-Kermadec Trench and Ozbourn Seamount Junction area, Tectonophysics, 112, 357-383, 1985.

Hafner, W., Stress distributions and faulting,Geol. Soc. Am. Bull., 62, 373-398, 1951.

Hamburger, M., R.K. Cardwell, and B.L. Isacks, Seismotectonics of the northern Philippine Island arc, in The Tectonic and Geologic Evolution of Southeast Asian Seas and Islands, Part 2, Geophys. Monogr. Ser., vol. 27, edited by D.E. Hayes, pp. 1-22, AGU, Washington, D.C., 1983.

Hamilton, W., Tectonics of the Indonesian region, U.S. Geol. Surv. Prof. Pap., 1078, 308 pp., 1979.

Hasegawa, A., N. Umino, A. Takagi, S. Suzuki, Y. Motoya, S. Kameya, K. Tanaka, and Y. Sawada, Spatial distribution of earthquakes beneath Hokkaido and northem Honshu, Japan (in Japanese with English abstract), J. Seismol. Soc. Jpn., $36,129-150,1983$.

Horsfield, W. T., An experimental approach to basementcontrolled faulting, Geol. Mijnbouw, 56, 363-370, 1977.

Hoshino, K., H. Koide, K. Inami, S. Iwamura, and S. Mitsui, Mechanical properties of Japanese Tertiary sedimentary rocks under high confining pressures, Rep. 244, 200 pp., Geol. Surv. of Japan, Kawasaki, 1972.
Hottman, C.E., J. H. Smith, and W. R. Purcell, Relationship among Earth stresses, pore pressure, and drilling problems offshore Gulf of Alaska, J. Pet. Technol., 31, 1477-1484, 1979.

Hubbert, M. K., Theory of scale models as applied to the study of geologic structures, Geol. Soc. Am. Bull., 48, 1459 $1520,1937$.

Huiqi, L., K. R. McClay, and D. Powell, Physical models of thrust wedges, in Thrust Tectonics, edited by K.R. McClay, pp. 71-81, Chapman and Hall, London, 1992.

Isacks, B.L., and M. Barazangi, Geometry of Benioff zones: Lateral segmentation and downwards bending of the subducted lithosphere, in Island Arcs, Deep Sea Trenches, and Back-Arc Basins, Maurice Ewing Ser. vol. 1, edited by M. Talwani, and W.C. Pitman III, pp. 99-114, AGU, Washington, D. C., 1977.

Iwasaki, T., H. Shiobara, A. Nishizawa, T. Kanazawa, K. Suyehiro, N. Hirata, T. Urabe, and H. Shimamura, A detailed subduction structure in the Kuril trench deduced from ocean bottom seismographic refraction studies, Tectonophysics, 165, 315-336, 1989.

Karig, D.E., J.G. Caldwell, and E.M. Parmentier, Effects of accretion on the geometry of the descending lithosphere, J. Geophys. Res., 81, 6281-6291, 1976.

Kawamura, T., and Y. Aoki, The Nankai Trough margin, record 55-8 in Seismic Images of Modern Convergent Margins Tectonic Structure, edited by R. von Huene, AAPG Stud. Geol., 26, 54-56, 1986.

Kroenke, L.W., C. Jouannic, and P. Woodward, Bathymetry of the Southwest Pacific, 1st ed., scale 1:6,440,000, CCOPSOPAC, Honiara, Solomon Islands, 1983.

Kulm, L.D., et al., Western North American continental margin and adjacent ocean floor off Oregon and Washington, Atlas 1, 32 sheets, Ocean Drill. Program Reg. Atlas Ser., Mar. Sci. Inst., Woods Hole, Mass., 1984.

Ladd, J.W., and R.T. Buffler (Eds.), Middle America Trench off Western Central America, Atlas 7, 21 sheets, Ocean Drill. Program Reg. Atlas Ser., Mar. Sci. Inst., Woods Hole, Mass., 1985.

Lallemand, S.E., Transfert de matière en zone de subduction (Earth Material Transfer in Subduction Zones) - Travaux publiés depuis 1990, Mem. Sci. Terre Univ. Pierre et Marie Curie, Paris, 92-27, vol.1, 189 pp., 1992a.

Lallemand, S.E., Transfert de matière en zone de subduction (Earth Material Transfer in Subduction Zones) - Réflexions sur les conséquences de l'érosion tectonique, $\mathrm{Mem}$. Sci. Terre Univ. Pierre et Marie Curie, Paris, 92-27, vol.2, 96 pp., $1992 b$.

Lallemand, S., and N. Chamot-Rooke, Sur la cause du décrochement senestre entre les fosses du Japon et des Kouriles: Subduction-collision d'un ancien volcan sousmarin (in French with English abstract), C. R. Acad. Sci. Paris, Ser. 2, 303, 1443-1448, 1986.

Lallemand, S., and X. Le Pichon, Coulomb wedge model applied to subduction of seamounts in the Japan Trench, Geology, 15, 1065-1069, 1987.

Lallemand, S.E. and J. Malavieille, L'érosion profonde des continents, Recherche, 249, 1388-1397, 1992.

Lallemand, S., R. von Huene, and R. Culotta, Subduction of the Daiichi Kashima seamount in the Japan trench, Tectonophysics, 160, 231-247, 1989.

Lallemand, S., J.-Y. Collot, B. Pelletier, C. Rangin, and J.-P. Cadet, Impact of oceanic asperities on the tectogenesis of modem convergent margins, Oceanol. Acta, 10, 17-30, 1990.

Lallemand, S. E., P. Schnurle, and S. Manoussis, Reconstruction of subduction zone paleogeometries and quantification of upper plate material losses caused by 
tectonic erosion, J. Geophys. Res., 97, 217-239, 1992a.

Lallemand, S. E., J. Malavieille, and S. Calassou, Effects of oceanic ridge subduction on accretionary wedges: Experimental modeling and marine observations, Tectonics, 11, 1301-1313, 1992b.

Le Pichon, X., and P. Henry, Erosion and accretion along subduction zones: A model of evolution, Proc. K. Ned. Akad. Wet., 95, 297-310, 1992.

Lewis, S.D., and D.E. Hayes, A geophysical study of the Manila trench, Luzon, Philippines, 2, Forearc basin structural and stratigraphic evolution, J. Geophys. Res., $89,9196-9214,1984$.

Lonsdale, P. F., A multibeam reconnaissance of the Tonga Trench axis and its intersection with the Louisville Guyot Chain, Mar. Geophys. Res., 8, 295-327, 1986.

Ludwig, W.J., et al., Sediments and structure of the Japan trench, J. Geophys. Res., 71, 2121-2137, 1966.

Malavieille, J., Modélisation expérimentale des chevauchements imbriqués: Application aux chaînes de montagnes, Bull. Soc. Géol. Fr., 7, 129-138, 1984.

Malavieille, J., S. Calassou, C. Larroque, S. Lallemand, and J.F. Stephan, Experimental modelling of accretionary wedges, Terra Abstr., 3, 367, 1991.

Malavieille, J., C. Larroque and S. Calassou, Modélisation expérimentale des relations tectonique/sédimentation entre bassin avant-arc et prisme d'accrétion, C. R. Acad. Sci. Paris, 316, 1131-1137, 1993.

Mammerickx, J., and S.M. Smith, Bathymetry of the southeast Pacific, scale 1:6,440,000, Scripps Inst. of Oceanogr., Univ. of Calif., La Jolla, 1978.

Mandl, G., Mechanics of tectonic faulting: Models and basic concepts, in Developments in Structural Geology, vol. 1, 407 pp., Elsevier, New York, 1988.

Maritime Safety Agency, Bathymetric chart of south-west Nippon, Map 6314, scale 1:1,000,000, Tokyo, 1983a.

Maritime Safety Agency, Bathymetric chart of north-east Nippon, Map 6312, scale 1:1,000,000, Tokyo, 1983b.

Maritime Safety Agency, Bathymetric chart of Hokkaido, Map 6311, scale 1:1,000,000, Tokyo, 1983c.

McCaffrey, R., Active tectonics of the eastern Sunda and Banda arcs, J. Geophys. Res., 93, 15163-15182, 1988.

Mc Clay, K.R., and P.G. Ellis, Analogue models of extensional fault geometries, in Continental Extensional Tectonics, edited by M.P. Coward, J.F. Dewey, and P.L. Hancock, Spec. Publ. Geol. Soc. London, 28, 109-125, 1987.

Moore, J. C., et al., Offscrapping and underthrusting of sediment at the deformation front of the Barbados Ridge: Deep Sea Drilling Project leg 78A, Geol. Soc. Am. Bull., 93, 1065-1077, 1982.

Moore, J. C., Tectonics and hydrogeology of accretionary prisms: Role of the décollement zone, J. Struct. Geol., II, 95-106, 1989.

Moore, J. C., and R. von Huene, Abnormal pore pressure and hole instability in forearc regions: A preliminary report, report, 29 pp., Ocean Margin Drill. Proj., Menlo Park. Calif., 1980.

Moore, G. F., T. H. Shipley, P. L. Stoffa, D. E. Karig, A. Taira, S. Kuramoto, H. Tokuyama, and K. Suyehiro, Structure of the Nankai Trough accretionary zone from multichannel seismic reflection data, J. Geophys. Res., $95,8753-8765,1990$ a.

Moore, J. C., D. Orange, and L. D. Kulm, Interrelationship of fluid venting and structural evolution: Alvin observations from the frontal accretionary prism, Oregon, $J$. Geophys. Res., 95, 8795-8808, 1990 b.

Mulugeta, G., Modelling the geometry of Coulomb thrust wedges, J. Struct. Geol., 10, 847-859, 1988.

Murauchi, S., T. Asanuma, H. Taguchi, H. Kinoshita, I.
Yokoyama, H. Nakatani, T. Yokota, and K. Tanaka, Crustal structure of the island-arc slope and the trench off Sanriku and mechanism of subduction (in Japanese), Mar. Sci., 10, 207-214, 1978.

Nagumo, S., J. Kasahara, and S. Koresawa, OBS airgun seismic refraction survey near sites 441 and 434 (J-1A), 438 and 439 (J-12), and proposed site J-2B: Legs 56 and 57, DSDP, 1, Initial Rep. Deep Sea Drill. Proj., 56-57, 459-462, 1980.

Pelletier, B., and J. Dupont, Effets de la subduction de la ride de Louisville sur l'arc des Tonga-Kermadec, Oceanol. Acta, 10, 57-76, 1990.

Platt, J. P., Thrust mechanics in highly overpressured accretionary wedges, J. Geophys. Res., 95, 9025-9034, 1990.

Pontoise, B., et al., La subduction de la ride de Louisville le long de la fosse des Tonga: Premiers résultats de la campagne Seapso (leg V), C. R. Acad. Sci. Paris, 303, 911-918, 1986.

Prévot, R., and J.-L. Chatelain, Sismicité et risque sismique à Vanuatu, Rapport 5-83, 551 pp., ORSTOM, Nouméa, New Caledonia, 1983.

Ramberg, H., Gravity, Deformation and the Earth's Crust, 2nd ed., 452 pp., Academic, San Diego, Calif., 1981.

Rangin, C., and M. Pubellier, Subduction and accretion of Philippine Sea Plate fragments along the Eurasian margin in Tectonics of Circum-Pacific Continental Margins, edited by J. Aubouin and J. Bourgois, pp. 139-164, TERRAPUB, Tokyo, 1990.

Reyners, M., A microearthquake study of the plate boundary. North Island, New Zealand, Geophys. J. R. Astron. Soc., 63, 1-22, 1980.

Robion, P., Etude de la déformation d'un prisme d'accrétion soumis à de l'Érosion tectonique: Approche expérimentale et numérique, Mém. DEA, 63 pp., Paris VI Univ., 1991.

Sakurai, M., A. Mogi, J. Chujo, and T. Miyazaki, Multichannel seismic reflection profiling off Joban District Northeast Japan, Rep. Hydrogr. Res., 16, 1-17, 1981.

Schnürle, P., Contribution à la compréhension des mécanismes d'érosion tectonique et à la quantification des flux de matière dans les zones de subduction, Mem. Sci. Terre Univ. Pierre et Marie Curie, Paris, 94-05, 173 pp., 1994.

Scholl, D.W., J. McCarthy, and H. Ryan, Forearc margin, Central Aleutian Ridge, in Seismic Images of Modem Convergent Margins Tectonic Structure, edited by R. von Huene, AAPG Stud. Geol., 26, 10-13, 1986.

Shipley, T.H., and G.F. Moore, Sediment accretion, subduction, and dewatering at the base of the trench slope off Costa Rica: A seismic reflection view of the décollement, J. Geophys. Res., 91, 2019-2028, 1986.

Speed, R.C., et al., Lesser Antilles Arc and adjacent terranes, Ocean Drill. Program Reg. Atlas Ser., Atlas 10, 27 sheets, Mar. Sci. Inst., Woods Hole, Mass., 1984.

Suppe, J., and J. H. Wittke, Abnormal pore-fluid pressures in relation to stratigraphy and structure in the active fold-andthrust belt of northwestern Taïwan, Pet. Geol. Taïwan, 14, 11-24, 1977.

von Huene, R., Structural diversities along modern convergent margins and the role of overpressured pore fluids in subduction zones, Bull. Soc. Geol. Fr., 7, 207-219, 1984.

von Huene, R. (Ed.), Seismic images of modern convergent margins tectonic structure, AAPG Stud. Geol., 26, $50 \mathrm{pp}$., 1986.

von Huene, R., and R. Culotta, Tectonic erosion at the front of the Japan Trench convergent margin, Tectonophysics, 160, 75-90, 1989.

von Huene, R., and S. Lallemand, Tectonic erosion along the 
Japan and Peru convergent margins, Geol. Soc. Am. Bull., 102, 704-720, 1990.

von Huene, R., and $H$. Lee, The possible significance of pore fluid pressures in subduction zones, AAPG Mem., 34, 781$791,1983$.

von Huene, R., and D.W. Scholl, Observations at convergent margins concerning sediment subduction, subduction erosion, and the growth of continental crust, $R e v$. Geophys., 29, 279-316, 1991.

von Huene, R., and D.W. Scholl, The retum of sialic material to the mantle indicated by terrigenous material subducted at convergent margins, Tectonophysics, 219, 163-175, 1993.

von Huene, R., M. Langseth, N. Nasu, and H. Okada, A summary of Cenozoic tectonic history along the IPOD Japan trench transect, Geol. Soc. Am. Bull., 93, 829-846, 1982.

von Huene, R., L. Kulm, J. Miller, and D. Hussong. The Peru continental margin, record sections 2 and 3, in Seismic Images of Modern Convergent Margins Tectonic Structure, edited by R. von Huene, AAPG Stud. Geol., 26, 37-40, 1986.

von Huene, R., et al., Morphotectonic features of the Costa Rican Pacific margin surveyed during the Sonne 76 cruise, in "Geologic and Tectonic Development of the Caribbean Plate Boundary in Southern Central America", Dedication: Richard Weyl (1915-1988), Spec. Publ., Geol. Soc. Am., in press, 1994.
Wadge, G., and J.B. Shepherd, Segmentation of the Lesser Antilles subduction zone, Earth Planet. Sci. Lett., 71, 297 304, 1984.

Westbrook, G.K., J.W., Ladd, P., Buhl, N., Bangs, and G.J., Tiley, Cross-section of an accretionary wedge: Barbados Ridge complex, Geology, 16, 631-635, 1988.

Wiens, D.A., Bathymetric effects on body waveforms from shallow subduction zone earthquakes and application to seismic processes in the Kurile trench, J. Geophys. Res., 94, 2955-2972, 1989.

Zhao, W.-L., D. M. Davis, F. A. Dahlen, and J. Suppe, Origin of convex accretionary wedges: Evidence from Barbados, J. Geophys. Res., 91, 10246-10258, 1986.

S.E. Lallemand and J. Malavieille, URA CNRS 1760 "Géophysique et Tectonique", Institut des Sciences de la Terre, de l'Eau et de l'Espace, Université Montpellier II, case 060, place E. Bataillon, 34095 Montpellier cédex 05, France. (email: lallem@dstu.univ-montp2.fr)

P. Schnürle, Laboratoire de Géologie Structurale, Département de Géotectonique, boîte 129, Université Pierre et Marie Curie, T 26-0, E1, 4 place Jussieu, 75252 Paris cédex 05, France.

(Received May 24, 1993; revised December 6, 1993; accepted January 10, 1994) 